\title{
Pseudomonas aeruginosa and $\mathrm{SPLA} \mathrm{A}_{2}$ IB stimulate ABCA1-mediated phospholipid efflux via ERK-activation of PPAR $\alpha-R X R$
}

\author{
Marianna AGASSANDIAN*1 , Olga L. MIAKOTINA*, Matthew ANDREWS*, Satya N. MATHUR* and Rama K. MALLAMPALLI* † \\ *Department of Internal Medicine, University of lowa, Roy J. and Lucille A. Carver College of Medicine, lowa City, IA 52242, U.S.A., † Department of Biochemistry, University of lowa, \\ Roy J. and Lucille A. Carver College of Medicine, lowa City, IA 52242, U.S.A., and $\ddagger$ Department of Veterans Affairs Medical Center, University of lowa, Roy J. and Lucille A. Carver \\ College of Medicine, lowa City, IA 52242, U.S.A.
}

\begin{abstract}
Bacterial infection triggers an acute inflammatory response that might alter phospholipid metabolism. We have investigated the acute-phase response of murine lung epithelia to Pseudomonas aeruginosa infection. Ps. aeruginosa triggered secretion of the pro-inflammatory lipase, $\mathrm{SPLA}_{2} \mathrm{IB}$ (phospholipase $\mathrm{A}_{2} \mathrm{IB}$ ), from lung epithelium. Ps. aeruginosa and $\mathrm{SPLA}_{2} \mathrm{IB}$ each stimulated basolateral PtdCho (phosphatidylcholine) efflux in lung epithelial cells. Pre-treatment of cells with glyburide, an inhibitor of the lipid-export pump, ABCA1 (ATP-binding cassette transporter A1), attenuated Ps. aeruginosa and $\mathrm{sPLA}_{2}$ IB stimulation of PtdCho efflux. Effects of Ps. aeruginosa and $\mathrm{SPA}_{2}$ IB were completely abolished in human Tangier disease fibroblasts, cells that harbour an $A B C A 1$ genetic defect. Ps. aeruginosa and SPLA $\mathrm{IB}_{2}$ induced the heterodimeric receptors, PPAR $\alpha$ (peroxisome-proliferator-activated receptor- $\alpha$ ) and RXR (retinoid X receptor), fac-
\end{abstract}

tors known to modulate $A B C A 1$ gene expression. Ps. aeruginosa and $\mathrm{sPLA}_{2}$ IB stimulation of PtdCho efflux was blocked with PD98059, a p44/42 kinase inhibitor. Transfection with MEK1 (mitogen-activated protein kinase/extracellular-signal-regulated kinase kinase 1), a kinase upstream of p44/42, increased PPAR $\alpha$ and RXR expression co-ordinately with increased ABCA1 protein. These results suggest that pro-inflammatory effects of $P s$. aeruginosa involve release of an $\mathrm{SPLA}_{2}$ of epithelial origin that, in part, via distinct signalling molecules, transactivates the $A B C A l$ gene, leading to export of phospholipid.

Key words: ATP-binding cassette transporter A1 (ABCA1), murine lung epithelium, phosphatidylcholine, Pseudomonas aeruginosa, secretory phospholipase $\mathrm{A}_{2}$ IB ( $\mathrm{sPLA}_{2} \mathrm{IB}$ ), surfactant.

\section{INTRODUCTION}

The alveolar epithelium provides a generous host epithelial airsurface interface that is continuously exposed to pathogens and inhaled particles. Pseudomonas aeruginosa is a respiratory pathogen in humans that infects epithelial cells of the airways and distal lung that leads to severe parenchymal injury [1]. The pathogenesis of acute and chronic Ps. aeruginosa infections involves both bacterial and host factors. Bacterial factors include attachment of bacteria to epithelial cells via expression of polar pili and flagella, and injection of effector proteins [ExoS, ExoT, ExoU and ExoY (exotoxin S, T, U and Y respectively)] elaborated by the type III secretory system [2,3]. These bacterial factors are responsible for triggering inflammatory responses, including secretion of pro-inflammatory cytokines that, via binding to specific receptors, activate signal transduction pathways [4-7]. One bacterial virulence factor, ExoU from $P$ s. aeruginosa, acts as a phospholipase as cytotoxicity of this toxin is blocked by inhibitors of $\mathrm{cPLA}_{2}$ and $\mathrm{iPLA}_{2}$ [cytosolic and $\mathrm{Ca}^{2+}$-independent $\mathrm{PLA}_{2}$ (phospholipase $\mathrm{A}_{2}$ ) respectively] [8].

Ps. aeruginosa also increases $\mathrm{SLA}_{2}$ (secretory $\mathrm{PLA}_{2}$ ) activity in bronchoalveolar lavage fluid and lung tissue [9]. $\mathrm{SPLA}_{2}$ may cause alveolar epithelial cell damage and pulmonary surfactant dysfunction, and enhance production of mediators that induce tissue injury [10]. Thus highly virulent bacteria such as Ps. aeruginosa can compromise lung function by increasing the hydrolysis of phospholipids that serve as integral components of cell mem- branes or surfactant. The molecular mechanisms by which Ps. aeruginosa might alter phospholipid metabolism in host cells, however, remain largely unknown.

$\mathrm{PLA}_{2}$ catalyses phospholipid hydrolysis at the $s n-2$ position of the glycerol backbone, with production of free fatty acids and lysophospholipids [11-13]. The superfamily of $\mathrm{PLA}_{2} \mathrm{~s}$ consists of two major classes, including low-molecular-mass secreted forms $\left(\mathrm{sPLA}_{2} \mathrm{~s}\right)$, containing ten groups, and high-molecular-mass cytosolic forms $\left(\mathrm{CPLA}_{2} \mathrm{~s}\right)$, containing three enzymes [14]. Both sPLA $_{2}$ and $\mathrm{CPLA}_{2}$ initiate the production of bioactive lipid mediators, but their relative inflammatory potency is tissue- and celltype-dependent [15]. $\mathrm{SPLA}_{2} \mathrm{~s}$, in particular, play an important role in both host defence and induction of inflammatory reactions via generation of lipid mediators and pro-inflammatory cytokines in acute lung injury $[9,12]$. High levels of $\mathrm{sPLA}_{2} \mathrm{IB}$ and $\mathrm{sPLA}_{2}$ IIA are observed in patients with the acute respiratory distress syndrome and other inflammatory disorders [16]. Aside from their enzymatic behaviour, $\mathrm{sPLA}_{2} \mathrm{~s}$ also trigger diverse biological responses via binding to specific receptors (M- or N-type) with different affinities [11]. Both sPLA IB $_{2}$ and sPLA $\mathrm{A}_{2}$ IIA act as highaffinity ligands to mouse $\mathrm{M}$-type receptors, thereby activating signal transduction pathways such as MAPKs (mitogen-activated protein kinases) [17]. Both $\mathrm{SPLA}_{2}$ IB and $\mathrm{SPLA}_{2}$ IIA stimulate $\mathrm{SPLA}_{2}$ IIA release from mesanglial cells, activate $\mathrm{cPLA}_{2}$ and induce expression of the $\operatorname{PPAR} \alpha$ (peroxisome-proliferator-activated receptor $\alpha$ ) independently of their enzymatic activity via interaction with M-type receptors or heparin sulfate proteoglycans

Abbreviations used: ABCA1, ATP-binding cassette transporter A1; apoAl/All, apolipoprotein Al/All; cfu, colony-forming units; DMEM, Dulbecco's minimal Eagle's medium; DPPC, dipalmitoyl phosphatidylcholine; DR, direct repeat; ERK, extracellular-signal-regulated kinase; Exo, exotoxin; GAPDH, glyceraldehyde-3-phosphate dehydrogenase; HDL, high-density lipoprotein; HSF, human skin fibroblast; LPS, lipopolysaccharide; LXR, liver X receptor; MAPK, mitogen-activated protein kinase; MEK, MAPK/ERK kinase; MLE-12 cell, murine lung epithelium cell; MOI, multiplicity of infection; PLA 2 , phospholipase $A_{2} ; c P L A_{2}$, cytosolic PLA $A_{2} ; s P L A_{2}$, secretory PLA $A_{2}$; PPAR $\alpha$, peroxisome-proliferator-activated receptor- $\alpha$; PtdCho, phosphatidylcholine; $\mathrm{RXR}$, retinoic $X$ receptor; SM, sphingomyelin; TCA, trichloroacetic acid; VBM, Vogel-Bonnel medium.

1 To whom correspondence should be addressed (email marianna-agassandian@uiowa.edu). 
[18-20]. These observations indicate that $\mathrm{sPLA}_{2} \mathrm{~s}$ exhibit both catalytic and non-catalytic receptor-dependent properties that modulate cellular responses.

$\operatorname{PPAR} \alpha$ is a nuclear receptor that functions as a key ligandactivated transcription factor that regulates genes involved in lipid metabolism. PPAR $\alpha$ regulates these genes via heterodimerization with obligate partners, such as the RXR (retinoid X receptor) and LXR (liver X receptor), and subsequent binding to PPREs (PPARresponsive elements) within target promoters [21-23]. PPAR $\alpha$ regulates synthesis of apoAI (apolipoprotein AI) and apoAII (apolipoprotein AII) that participate in HDL (high-density lipoprotein) particle formation. PPAR $\alpha$ and LXR heterodimerization also enhances expression of ABCAI (ATP-binding cassette transporter AI), a lipid pump that is involved in HDL synthesis that transports cellular phospholipids and cholesterol to apoAI [24-27]. Previous studies by us and others indicate that the ABCA1 transporter might play an important role in regulating lung phospholipid homoeostasis [28-30]. Mice harbouring targeted deletion of $A B C A 1$ exhibit respiratory distress and show abnormalities of surfactant phospholipid metabolism [30,31]. Furthermore, ABCA1 activation decreases surfactant PtdCho (phosphatidylcholine) levels, in part, via basolateral export of this phospholipid in alveolar type II epithelial cells [10,28]. These observations, together with prior studies showing that $P$ s. aeruginosa decreases PtdCho levels and increases lung phospholipase activity, led us to hypothesize that this bacterial pathogen might activate ABCA1 via distinct signalling mechanisms involving $\mathrm{sPLA}_{2}$. Thus we tested effects of Ps. aeruginosa and $\mathrm{SPLA}_{2}$ on ABCA1-mediated phospholipid export. Our results show that $P$ s. aeruginosa exploits an ABCA1 export pathway for PtdCho that appears to be driven by autocrine secretion of $\mathrm{SPLA}_{2}$ in murine lung epithelia.

\section{MATERIALS AND METHODS}

\section{Materials}

Bovine pancreas sPLA $\mathrm{A}_{2}$ IB was purchased from Sigma Chemicals. Ps. aeruginosa, strain PA103, was obtained from Dr Timothy Yahr (University of Iowa, Iowa City, IA, U.S.A.). MLE-12 (murine lung epithelial) cells, H441 and HepG2 cell lines were obtained from A.T.C.C. (Manassas, VA, U.S.A.), and CaCo-2 cells were a gift from Dr E. Schaefer and Dr J. Ordovas (Tufts University School of Medicine, New England Medical Center, Boston, MA, U.S.A.). Culture medium was from the University of Iowa Tissue Culture and Hybridoma Facility. Immortalized HSFs (human skin fibroblasts) obtained from normal (EB86-282t) and Tangier disease patients (JKWt) were generously provided by $\mathrm{Dr}$ John Oram (Department of Medicine, University of Washington, Seattle, WA, U.S.A.). Glyburide was obtained from Calbiochem. MK 886 and MJ33 inhibitors were from Sigma Chemicals. Transwell plates with polyester membranes $(0.4 \mu \mathrm{m}$ pore size, $24 \mathrm{~mm}$ diameter) were obtained from Corning. The ECL $^{\circledR}$ (enhanced chemiluminescence) Western blotting detection reagents were from Pierce Biotechnology and Amersham Biosciences. The rabbit polyclonal anti-ABCA1 antibody was purchased from Novus Biologicals. Anti-(phospho p44/p42) and anti-(total p44/p42) antibodies were from Cell Signaling Technologies. Anti-(sPLA 2 IIA), anti-(sPLA 2 X), anti-(sPLA $\mathrm{V})$ and anti-PPAR $\alpha$ antibodies were from Cayman Chemicals. Anti-(sPLA 2 IB) antibodies were obtained from Upstate Biotechnology. Anti-RXR and anti-LXR antibodies were from Santa Cruz Biotechnology. Reverse-transcription reagents and SYBR Green master mix were from Invitrogen and Applied Biosystems respectively. HDL was obtained from Intracell, and Apo-AI was from Sigma Chemicals. The FuGENE6 transfection reagent was purchased from Roche Diagnostics. Salmonella enterica serovar Typhi and Escherichia coli LPS (lipopolysaccharide) were obtained from Sigma Chemicals. $\left[{ }^{3} \mathrm{H}\right]$ Cholesterol $(48.3 \mathrm{Ci} / \mathrm{mmol})$ was purchased from PerkinElmer Life Sciences. [methyl$\left.{ }^{3} \mathrm{H}\right]$ Choline chloride was obtained from American Radiolabeled Chemicals. For animal studies, 6-8 week-old male C57BL/6J mice (20-25 g) were obtained from Jackson Laboratories. All experimental procedures involving mice were performed in accordance with the protocols approved by the University of Iowa Animal Care and Use Committee.

\section{Cell culture}

MLE-12 cells were maintained in Hite's medium with $2 \%(\mathrm{v} / \mathrm{v})$ FBS (fetal bovine serum) at $37^{\circ} \mathrm{C}$ in atmosphere containing $5 \%$ $\mathrm{CO}_{2}$. After reaching 80-100\% confluence, the cells were harvested using $0.25 \%$ trypsin with $0.1 \%$ EDTA and plated on to sixwell, 12-well or 60-mm tissue culture dishes or on transwell dishes to study basolateral efflux [28]. After incubation overnight, the medium was changed to serum-free Hite's medium for $\sim 2 \mathrm{~h}$, and then changed again to fresh serum-free medium. Cells were incubated with this serum-free medium alone (control medium) or in combination with various amounts of $P$ s. aeruginosa or $\mathrm{SPLA}_{2}$ IB for various times. HSFs were grown in DMEM (Dulbecco's minimal Eagle's medium) with $10 \%$ (v/v) FBS at $37^{\circ} \mathrm{C}$ containing $5 \% \mathrm{CO}_{2}$. HSF cells were plated on six-well plates and were grown to $70 \%$ confluence. Subconfluent cells were exposed to Ps. aeruginosa [MOI (multiplicity of infection) of 5] or $\mathrm{SPLA}_{2}$ IB $(100 \mu \mathrm{g} / \mathrm{ml})$.

CaCo-2 cells, a colonic cancer cell line, were cultured in T-75 flasks in DMEM with $10 \%(\mathrm{v} / \mathrm{v})$ FBS. Once the flasks reached $80 \%$ confluence, the cells were split and plated at a density of $0.2 \times 10^{5}$ cells/well on polycarbonate micropore membranes $(0.4 \mu \mathrm{m}$ pore size, $24 \mathrm{~mm}$ diameter) inserted into transwells and cultured for 14 days to obtain a confluent monolayer of differentiated cells. The human hepatocellular liver carcinoma cell line (HepG2) was maintained in MEM (minimum essential medium) with Earle's BSS (balanced salt solution) and $10 \%$ (v/v) FBS at $37{ }^{\circ} \mathrm{C}$ in atmosphere containing $5 \% \mathrm{CO}_{2} . \mathrm{H} 441$ cells, a human lung cell line with characteristics of Clara cells, were maintained in RPMI 1640 medium with $5 \% \mathrm{FBS}$ at $37^{\circ} \mathrm{C}$ in atmosphere containing $5 \% \mathrm{CO}_{2}$.

\section{Preparation of Ps. aeruginosa}

Ps. aeruginosa (PA103) was maintained in VBM (Vogel-Bonnel medium). Bacteria originating from frozen stocks were inoculated on VBM plates overnight. The next day, colonies were scraped and grown by rotary shaking at $37^{\circ} \mathrm{C}$ to reach exponential growth phase $\left(D_{540}=0.65-0.7\right)$ in tryptic soy broth supplemented with $100 \mathrm{mM}$ monosodium glutamate and $1 \%$ glycerol. Infection of cells was performed with an MOI of 5, an optimal PA103 concentration for cells as described previously [32].

\section{In vivo infection with Ps. aeruginosa}

Six-week-old male C57BL/6J mice weighing 20-25 g were deeply anaesthetized intraperitoneally with ketamine (60$100 \mathrm{mg} / \mathrm{kg})$ and xylazine $(10 \mathrm{mg} / \mathrm{kg})$. Mice were then intratracheally injected with control agar particles or bacteria agar particles $\left[10^{4}-10^{5} \mathrm{cfu}\right.$ (colony-forming units) in $50 \mu \mathrm{l}$ of control agar particles]. After $1 \mathrm{~h}$, mice were killed with an intraperitoneal injection of pentobarbital $(150 \mathrm{mg} / \mathrm{kg})$, the lungs were lavaged, and surfactant pellets were isolated as described in [32]. Total RNA and lung homogenates were also harvested. Primary alveolar type II epithelial cells were isolated as described in [32]. 


\section{Phospholipid efflux}

Confluent monolayers on transwells were pulsed with $2 \mu \mathrm{Ci}$ of [methyl $\left.-{ }^{3} \mathrm{H}\right]$ choline chloride or $2.5 \mu \mathrm{Ci}$ of $\left[\right.$ methyl $\left.-{ }^{3} \mathrm{H}\right]$ cholesterol at the apical surface for 18-24 h, washed three times, and exposed apically to Ps. aeruginosa, $\mathrm{SPLA}_{2}$ IB or LPS from E. coli or Salmonella Typhi in the presence of $20 \mu \mathrm{g} / \mathrm{ml} \mathrm{HDL}$ or $10 \mu \mathrm{g} / \mathrm{ml}$ ApoAI acceptor. Lipids were extracted from basolateral and apical medium and analysed for PtdCho, SM (sphingomyelin) or lyso-PtdCho efflux using TLC in chloroform/methanol/light petroleum/ethanoic (acetic) acid/boric acid (40:20:30:10:1.8, by vol.) and liquid-scintillation counting [33]. For inhibitor studies, after pulsing with $\left[\right.$ methyl- $\left.{ }^{3} \mathrm{H}\right]$ choline chloride, cells were preincubated apically with glyburide $(250 \mu \mathrm{M})$ for $1 \mathrm{~h}$ and then exposed to Ps. aeruginosa or $\mathrm{SPLA}_{2} \mathrm{IB}$ with HDL added to apical and basolateral medium. For determination of PtdCho efflux in HSFs, the subconfluent cells were labelled with $2 \mu \mathrm{Ci}$ of [methyl${ }^{3} \mathrm{H}$ ]choline chloride for $18-20 \mathrm{~h}$, and unincorporated radiolabel was removed by washing cells three times before exposure to $P S$. aeruginosa or $\mathrm{SPLA}_{2}$ IB with Apo-AI $(10 \mu \mathrm{g} / \mathrm{ml})$ for $2 \mathrm{~h}$. PtdCho efflux values were expressed as a percentage of total radiolabelled PtdCho recovered in the cells, basolateral and apical medium.

\section{PtdCho and DPPC (dipalmitoyl phosphatidylcholine) analysis}

PtdCho biosynthesis was measured as the rate of incorporation of $\left[\right.$ methyl $\left.-{ }^{3} \mathrm{H}\right]$ choline chloride into PtdCho. Cells were pulsed for the last $2 \mathrm{~h}$ of incubation with $2 \mu \mathrm{Ci}$ of $\left[\right.$ methyl $\left.-{ }^{3} \mathrm{H}\right]$ choline chloride, lipids were extracted and resolved by TLC, and PtdCho or DPPC was quantified by TLC scanning or liquid-scintillation counting [28]. Levels of DPPC mass was measured using a phosphorus assay as described [28].

\section{Immunoblot analysis}

Equal amounts of proteins in cell lysates were separated on $10 \%$ polyacrylamide gels and probed with various antibodies [against ABCA1, sPLA 2, PPAR $\alpha$, RXR, LXR, ERK1/2 (extracellularsignal-regulated kinase $1 / 2$ ) and $\beta$-actin] as described in [28]. Each antibody was used at a concentration as recommended by the manufacturer. For secreted proteins, $5 \mathrm{ml}$ of the culture medium was precipitated with $60 \%$ TCA (trichloroacetic acid) and $1.5 \%$ sodium desoxycholate, and immunoblots were probed using a polyclonal antibody against $\mathrm{SPA}_{2}$ IB or $\mathrm{sPLA}_{2}$ IIA.

\section{Real-time PCR analysis}

Total cellular RNA was isolated using Tri-Reagent. ABCA1 transcripts were detected by real-time PCR using mouse ABCA1 primers and rodent GAPDH (glyceraldehyde-3-phosphate dehydrogenase) as an internal control as described in [28]. ABCA1 transcript detection primers were 5'-ACTAGTGCCAAGTTGCTCAG-3' (forward) and 5'-TAAGTCCCTGCCCTTTGTACAAC-3' (reverse). ABCG1 primers were 5'-GGGATCAGAACAGTCGCCTG-3' (forward) and 5'-CGAGGTCTCTCTTATAGTCAGCGTC-3' (reverse). ABCG5 primers were 5'-TGATTGGCAGCTATAATTTTGGG-3' (forward) and 5'-GTTGGGCTGCGATGGAAA-3'.

\section{Construction of $A B C A 1$ promoter-reporter plasmids}

Human $A B C A 1$ promoter fragments were generated using human genomic DNA (GenBank ${ }^{\circledR}$ accession number AF287262) as a template by PCR with Pfu Turbo DNA polymerase (Stratagene). Forward and reverse primers contained restriction sites for EcoRV and HindIII respectively (see below): -949 forward, 5'-cggatatcAAAGGCAAACAGAGAAGTTG-3', - 205 forward, 5'-cggatatcTCCCTAGATGTGTCGTGG-3', - 77 forward, 5'-cggatatcACAGGCTTTGACCGATAG-3', - 49 forward, 5'-ggatatcGCTCGGTGCAGCCGAATC-3', + 274 reverse, 5'gtacaagcttTGGCCTCGAAACAAAACAATAACG-3', - 77mut forward, 5'-AGGGAGAGCACAGGCTTTAAATGATAGTAGTATCTGCGCTCGGTGCAGCCG-3' and - 77mut reverse, 5' $^{\prime}$ CGGCTGCACCGAGCGCAGATACTACTATCATTTAAAGCCTGTGCTCTCCCT-3'. Lower-case letters indicate added restriction sites, underlined letters indicate DR-4 (direct repeat 4) site and bold letters indicate mutated nucleotides.

PCR products were resolved on agarose gels, purified, and directionally cloned into pGL4-basic (Promega). The constructs were verified by restriction enzyme digestion and sequencing. A DR-4 mutant was prepared using QuikChange Site-Directed Mutagenesis kit (Stratagene) according to the manufacturer's instructions (see primers above) and verified by DNA sequencing.

\section{Transfectional analysis}

For analysis of $A B C A 1$ promoter activity, MLE-12 cells were plated into 12-well tissue culture dishes and allowed to reach $\sim 50-60 \%$ confluence. The medium was switched to serumfree conditions, and transient transfection was performed with $0.75 \mu \mathrm{g} /$ well pGL4-ABCA1 plasmids in FuGENE6 transfection reagent overnight. Co-transfection with $0.25 \mu \mathrm{g} / \mathrm{well} \mathrm{pSV}-\beta$ galactosidase was used to control for transfection efficiency. Cells were lysed with reporter lysis buffer for analysis of luciferase and $\beta$-galactosidase activities. For MEK1 (MAPK/ERK kinase 1) effects, cells were transfected with MEK1 plasmid $(4 \mu \mathrm{g} / 60-\mathrm{mm}$ dish) overnight. The next day, cells lysates were processed for immunoblot analysis.

\section{Statistical analysis}

Statistical analysis was performed using Student's $t$ test [34]. Results are presented as means \pm S.E.M. for three to six independent experiments.

\section{RESULTS}

\section{Ps. aeruginosa induces PtdCho efflux in lung epithelia}

MLE-12 cells were cultured in plastic dishes or in transwell dishes to assess phospholipid efflux (Figure 1). After exposure to $P s$. aeruginosa $(\mathrm{MOI}=5)$ or $\mathrm{sPLA}_{2}$ IB $(100 \mu \mathrm{g} / \mathrm{ml})$, medium was harvested, and lipids were extracted and processed for PtdCho efflux. Ps. aeruginosa triggered a 4-5-fold increase in [methyl$\left.{ }^{3} \mathrm{H}\right] \mathrm{PtdCho}$ efflux on plastic dishes (Figure 1A) and produced a 2fold induction of basolateral PtdCho efflux in transwell dishes at 2 and $4 \mathrm{~h}$ compared with control (Figure 1B). Similarly to effects

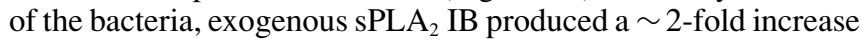
in PtdCho export (Figures 1C and 1D) and yet inhibited apical PtdCho secretion (Figure 1E). Of note, the kinetics of increased basal secretion of phospholipid by $\mathrm{SPLA}_{2}$ preceded inhibition of apical export, suggesting that these routes for lipid export are linked. Lastly, in preliminary results, these effects on export by sPLA $_{2}$ IB were also associated with a $\sim 60 \%$ decrease in choline incorporation into PtdCho, suggesting that phospholipid synthesis is also reduced (results not shown).

To determine the specificity of lipid efflux, MLE-12 cells were cultured in transwells, labelled with $\left[{ }^{3} \mathrm{H}\right]$ cholesterol, and subsequently exposed to Ps. aeruginosa $(\mathrm{MOI}=5)$ or $\mathrm{sPA}_{2} \mathrm{IB}$ (100 $\mu \mathrm{g} / \mathrm{ml}$ ) (Figure 2). The results demonstrate that there was no significant induction of cholesterol efflux by Ps. aeruginosa and a tendency for down-regulation of cholesterol efflux by $\mathrm{SPLA}_{2}$ IB (Figure 2A). We next assessed the specificity of responses 


\section{Basolateral}

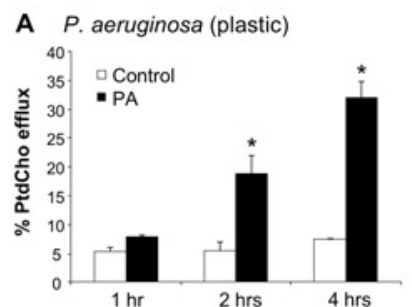

B P. aeruginosa (transwell)

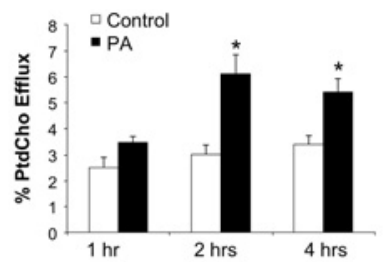

C SPLA2 IB (plastic)

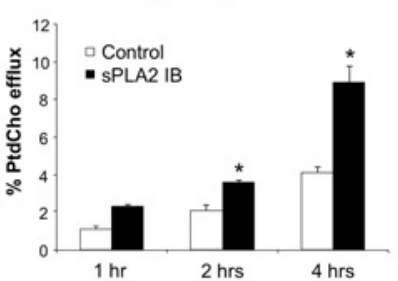

D SPLA2 IB (transwell)

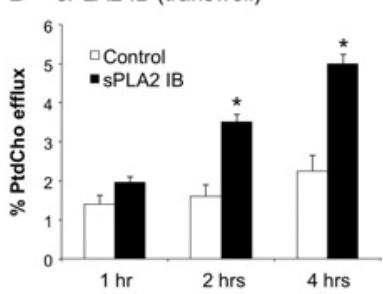

Apical

E SPLA2 IB (apical efflux)

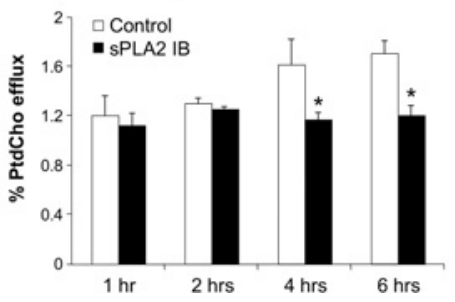

Figure $1 P$ s. aeruginosa and SPLA $I B$ induce PtdCho efflux in lung epithelia

Effect of Ps. aeruginosa (PA) on basolateral PtdCho efflux was assayed in MLE-12 cells plated in $60 \mathrm{~mm}$ plastic and transwell dishes, labelled with [methyl- $\left.{ }^{3} \mathrm{H}\right]$ choline and in the presence of $20 \mu \mathrm{g} / \mathrm{ml} \mathrm{HDL}$ as a PtdCho acceptor. Cells were exposed to Ps. aeruginosa $(\mathrm{MOI}=5)$ for various times (A, B). Effect of $100 \mu \mathrm{g} / \mathrm{ml}$ sPLA, IB on basolateral (C, D) and apical (E) efflux was measured under similar conditions. The cells and basolateral and apical medium were harvested separately after exposure to $P$ s. aeruginosa and $\mathrm{SPLA} \mathrm{A}_{2} \mathrm{IB}$ and processed for PtdCho analysis. ${ }^{\star} P<0.05$ compared with control. Results are means \pm S.E.M. for three to five independent experiments.

to Ps. aeruginosa in other epithelia and to other phospholipids (Figures 2B and 2C). Significant effects on PtdCho efflux were observed in MLE-12 cells and HepG2 cells, the latter only after prolonged exposure to the pathogen (Figure 2B). Ps. aeruginosa and $\mathrm{SPLA}_{2}$ IB did not trigger export of SM or lyso-PtdCho (Figure 2C). To investigate whether effects were unique to $P S$. aeruginosa, LPS from other Gram-negative bacteria were tested. Indeed, E. coli did not induce PtdCho efflux from cells, and Salmonella Typhi just slightly induced PtdCho efflux (Figure 2D). Thus Ps. aeruginosa and sPLA $\mathrm{A}_{2}$ IB selectively stimulate export of the major phospholipid in lung epithelia. Bacterial effects on PtdCho export, however, were not restricted to MLE-12 cells.

\section{Ps. aeruginosa and SPLA $A_{2}$ IB up-regulate ABCA1 expression in lung epithelia}

Our previous studies demonstrated that the lipid pump, ABCA1, serves as a basolateral PtdCho exporter in lung epithelial cells [28]. To examine whether Ps. aeruginosa increases PtdCho efflux by modulating ABCA1, we first investigated immunoreactive levels of ABCA1 after bacterial infection. For these experiments, we used a commercially available anti-ABCA1 antibody that cross-reacts with murine ABCA1 with a predicted molecular mass of $\sim 200 \mathrm{kDa}$. Immunoblotting revealed that Ps. aeruginosa increased ABCA1 protein levels (Figure 3A). Next, changes in
ABCA1 were correlated with levels of steady-state ABCA1 transcripts after Ps. aeruginosa infection (Figure 3B). Quantitative PCR analysis revealed that Ps. aeruginosa increased expression of ABCA1 transcripts ( 1.5-2.5-fold) (Figure 3B). Of note, changes in ABCA1 mass and mRNA in response to bacterial infection temporally preceded export of PtdCho from cells. These data suggest that Ps. aeruginosa transcriptionally activates the $A B C A l$ gene and that this transporter might mediate functional effects of this pathogen on phospholipid export.

To determine whether effects of PS. aeruginosa are recapitulated with another pro-inflammatory molecule activated by the pathogen, cells were incubated with $\mathrm{PLA}_{2} \mathrm{IB}$, and then cellular lysates were processed for ABCA1 immunoblotting and mRNA analysis (Figures 3C-3D). Immunoblotting demonstrated induction of ABCA 1 levels by $\mathrm{SPLA}_{2}$ IB over a $1-4 \mathrm{~h}$ period of analysis (Figure 3C). The phospholipase also increased $A B C A 1$ mRNA levels in murine lung epithelium (Figure 3D). In addition to ABCA1, other ATP-binding cassette transporters might mediate cellular efflux of phospholipids. Quantitative PCR revealed that Ps. aeruginosa stimulated expression of ABCA1 transcripts, but not ABCG1 and ABCG5 (Figure 3E).

To examine effects of $P$ s. aeruginosa in vivo, mice were infected with PA103. After $1 \mathrm{~h}$, levels of DPPC, the major surface-active phospholipid in lavage, decreased substantially compared with the control (Figure 4A). Immunoblot analysis and quantitative PCR demonstrated induction of ABCA1 protein and mRNA levels in lung (but not liver) with PA103 infection that varied as a function of inoculum size (Figures $4 \mathrm{~B}$ and $4 \mathrm{C}$ ). PtdCho efflux was also determined in freshly isolated type II epithelial cells after $P S$. aeruginosa $(\mathrm{MOI}=5)$ infection. Indeed, PA103 increased PtdCho efflux in these cells, an effect attenuated using glyburide, an ABCA1 inhibitor (Figure 4D). Thus Ps. aeruginosa effects on PtdCho efflux in vitro are also observed in vivo and in primary murine lung epithelial cells.

To evaluate further a mechanistic role for ABCA1 in mediating functional responses to $P s$. aeruginosa and $\mathrm{SPLA}_{2} \mathrm{IB}$, we used HSFs obtained from normal and Tangier disease patients that express a defective $A B C A l$ gene, and glyburide (Figure 5). Indeed, $P$ s. aeruginosa and $\mathrm{SPLA}_{2}$ IB stimulation of PtdCho efflux that was detected in HSFs was not observed in Tangier disease cells (Figures 5A and 5C). Furthermore, stimulation of cellular basolateral transport of the phospholipid by $P S$. aeruginosa and $\mathrm{sPLA}_{2}$ IB in MLE-12 cells was blocked with glyburide (Figures 5B and 5D). Thus these studies indicate that effects of Ps. aeruginosa and $\mathrm{SPA}_{2}$ IB on PtdCho efflux in lung epithelia are mediated, in part, by ABCA1.

\section{Ps. aeruginosa and $S P L A_{2}$ IB stimulate phospholipase secretion from lung epithelial cells}

Ps. aeruginosa and $\mathrm{sPLA}_{2}$ IB each triggered release of secretory phospholipases from lung epithelia into the culture medium (Figure 6). First, to determine whether these phospholipases were released from Ps. aeruginosa or host cells, we probed for $\mathrm{sPLA}_{2}$ IB in medium cultured with bacteria in the presence or absence of lung epithelial cells. As shown in Figure 6A (lanes 1-3), sPLA IB was not detected in bacterially infected culture medium devoid of lung epithelial cells; sPLA IB $_{2}$ was detected, however, when bacteria were co-cultured with cells, indicating that the origin of the $\mathrm{sPLA}_{2} \mathrm{IB}$ was likely to be derived from epithelial cells. This was observed regardless of whether bacteria were incubated with MLE-12 cells or primary murine type II cells that synthesize surfactant (Figures 6B and 6C).

Ps. aeruginosa and exogenously applied sPLA $\mathrm{A}_{2}$ IB also produced a robust increase in secretion of another related 


\section{A MLE}

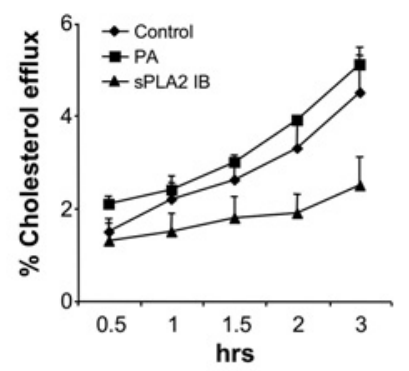

C

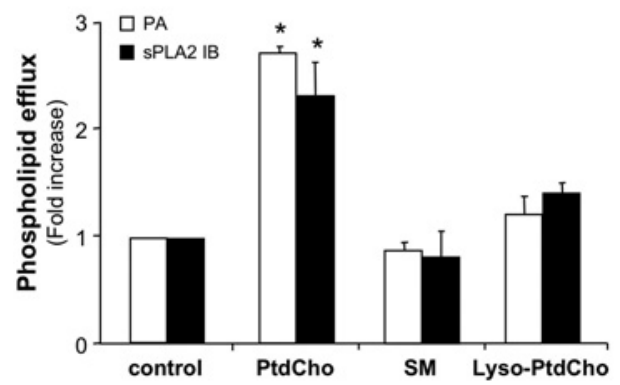

B Epithelial cells

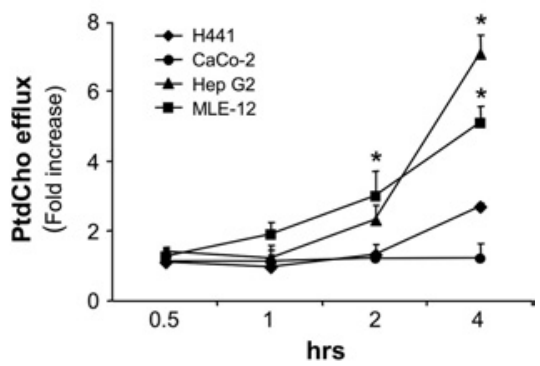

D

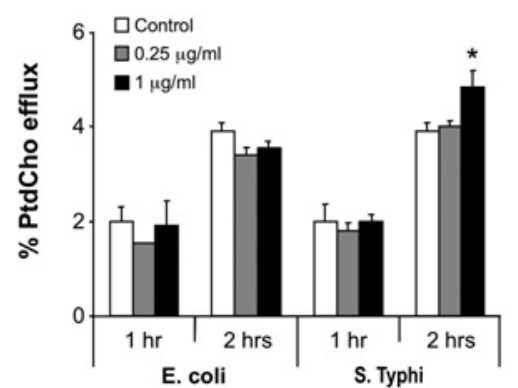

Figure 2 Ps. aeruginosa triggers phospholipid efflux selectively

(A) Effect of PS. aeruginosa (PA) and SPLA, IB on cholesterol efflux in MLE-12 cells plated in transwells and labelled with $\left[{ }^{3} \mathrm{H}\right]$ cholesterol. Cells were exposed to $P$ s. aeruginosa (MOI $=5$ ) and sPLA IB (100 $\mu \mathrm{g} / \mathrm{ml})$ for various times after labelling and processed for cholesterol efflux. (B) Effect of Ps. aeruginosa on PtdCho efflux in different types of epithelial cells. (C) Effect of Ps. aeruginosa (PA) and sPLA IB on efflux of SM and lyso-PtdCho in MLE-12 cells after $2 \mathrm{~h}$ of exposure to agonists. (D) Effect of LPS from E. coli and Salmonella Typhi (S. Typhi) on PtdCho efflux in MLE-12 cells. ${ }^{*} P<0.05$ compared with control. Results are means \pm S.E.M. for three independent experiments.

A.

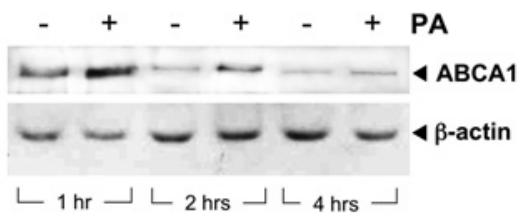

C.

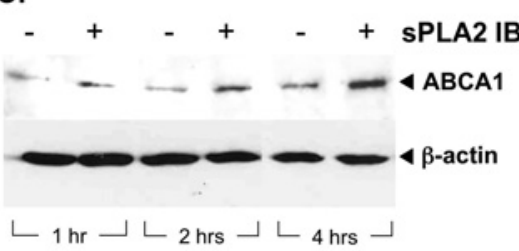

E.

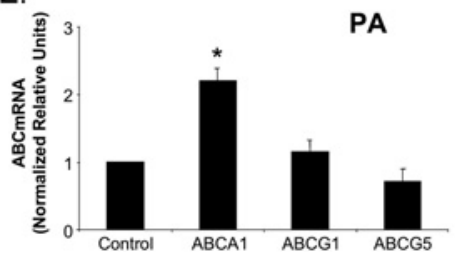

B.

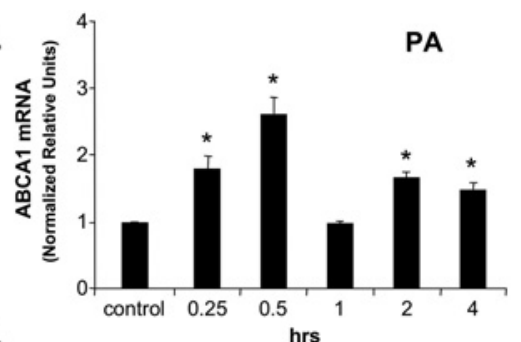

D.

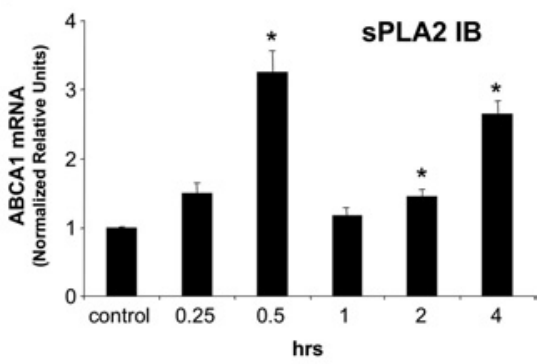

Figure 3 Ps. aeruginosa and SPLA 2 IB stimulate expression of ABCA1 in lung epithelial cells

MLE-12 cells were incubated with $(+)$ or without $(-)$ Ps. aeruginosa $(\mathrm{MOI}=5)(\mathrm{PA})(\mathbf{A}, \mathbf{B})$ or $\mathrm{SPLA} \mathrm{A}_{2}(100 \mu \mathrm{g} / \mathrm{ml})(\mathbf{C}, \mathbf{D})$ for various times. $(\mathbf{A}, \mathbf{C}) \mathrm{ABCA1}$ and $\beta$-actin levels were determined by immunoblotting using $\sim 100 \mu \mathrm{g}$ of cell lysate protein, resolution by SDS/10\% PAGE and probing with anti-ABCA1 or $\beta$-actin polyclonal antibodies. (B, D) PS. aeruginosa and sPLA 2 induce ABCA1 mRNA levels in MLE-12 cells. Cultured cells were infected with or without $P$ s. aeruginosa for various times or cultured with $\mathrm{PPLA}$, and total cellular RNA was harvested for analysis of $A B C A 1 \mathrm{mRNA}$ by real-time PCR. (E) MLE-12 cells were exposed to PS. aeruginosa $(\mathrm{MOI}=5)(\mathrm{PA})$ for $2 \mathrm{~h}$, and total cellular RNA was harvested for analysis of $A B C G 1$ and $A B C G 5 \mathrm{mRNA}$ by real-time PCR. Results are mean \pm S.E.M. relative units, which were normalized to murine GAPDH, for three independent experiments. ${ }^{*} P<0.05$ compared with control. 
A

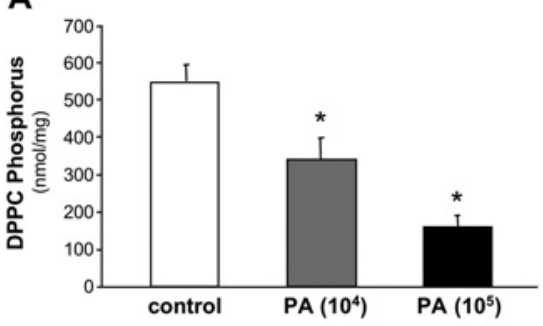

C

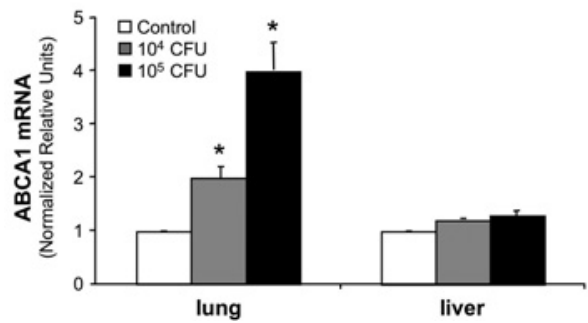

B
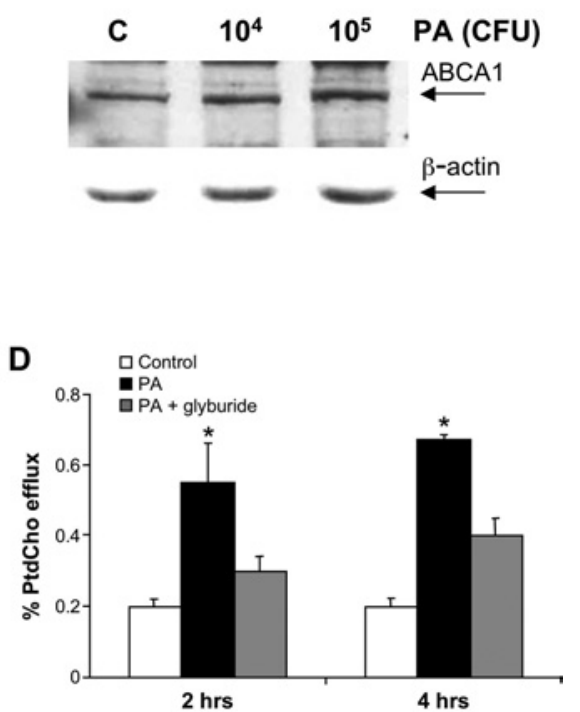

\section{Figure 4 Ps. aeruginosa regulates PtdCho export in vivo}

C57BL/6J mice were intratracheally administrated with Ps. aeruginosa strain PA103 (PA) using either control agar particles or bacterial agar particles $\left(10^{4}-10^{5} \mathrm{cfu}\right)$. After $1 \mathrm{~h}$, mice were killed, the lungs were lavaged, and surfactant pellets were isolated. (A) Surfactant pellets were analysed for DPPC levels, expressed as nmol of lipid phosphorus/mg of protein. (B) The lungs were processed for ABCA1 and $\beta$-actin levels by immunoblot analysis. (C) Total mRNA was harvested from lung and liver for analysis of ABCA1 mRNA by real-time PCR. (D) Primary mouse type II cells were isolated and labelled with [methyl- ${ }^{3} \mathrm{H}$ ]choline for $20 \mathrm{~h}$, exposed to glyburide $(250 \mu \mathrm{M})$ for $1 \mathrm{~h}$, and then incubated with or without PA103 (MOI $\left.=5\right)$ in the presence of $\mathrm{HDL}(20 \mu \mathrm{g} / \mathrm{ml})$. Medium and cells were harvested for PtdCho analysis. ${ }^{\star} P<0.05$ compared with control. Results are means \pm S.E.M. for three independent experiments.

A

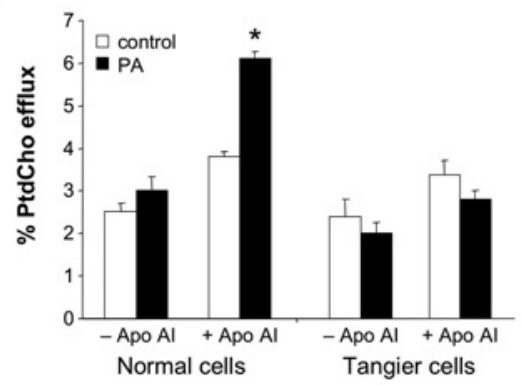

C

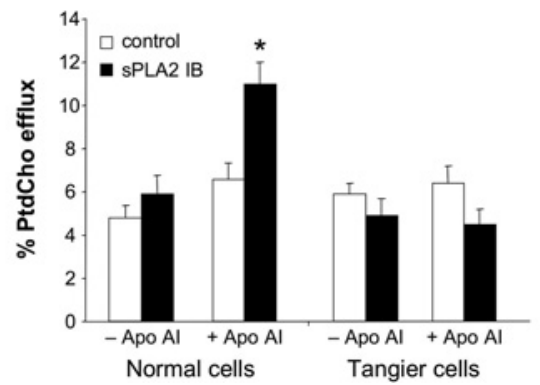

B

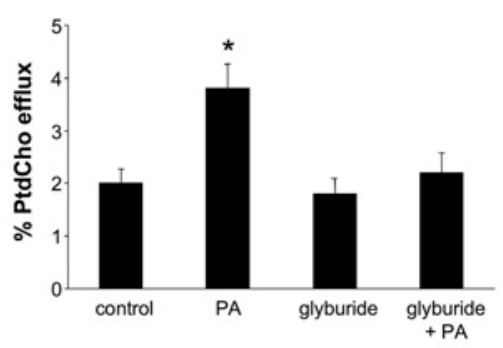

D

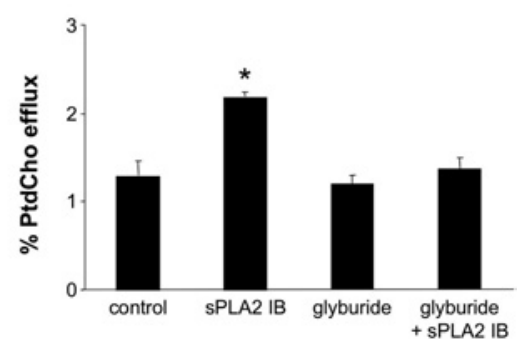

\section{Figure 5 Ps. aeruginosa and $S P L A_{2}$ IB regulate PtdCho export via ABCA1 in lung epithelia}

(A, C) Immortalized HSFs obtained from normal and Tangier disease patients were plated on plastic dishes, labelled with [methyl- $\left.{ }^{3} \mathrm{H}\right]$ choline for $20 \mathrm{~h}$, and then incubated with or without $P S$. aeruginosa (MOI = 5) (PA) (A) or sPLA IB (100 $\mu \mathrm{g} / \mathrm{ml})(\mathbf{C})$ using apoAl $(10 \mu \mathrm{g} / \mathrm{ml})$ as a PtdCho acceptor. Medium and cells were harvested after $2 \mathrm{~h}$ of exposure to PS. aeruginosa or sPLA $\mathrm{A}_{2} \mathrm{~B}$ and processed for PtdCho analysis. (B, D) Effect of pharmacological ABCA1 inhibition on PS. aeruginosa (B) or SPLA IB (D) -induced basolateral efflux was assayed in transwell dishes. Cells were labelled with $\left[\right.$ methyl- $\left.{ }^{3} \mathrm{H}\right]$ choline for $20 \mathrm{~h}$, exposed to glyburide $(250 \mu \mathrm{M})$ and then incubated with or without PS. aeruginosa $(\mathrm{MOI}=5)$ or sPLA $\mathrm{IB}(100 \mu \mathrm{g} / \mathrm{ml})$ for $2 \mathrm{~h}$ in the presence of HDL $(20 \mu \mathrm{g} / \mathrm{ml})$. Medium and cells were harvested for PtdCho analysis. ${ }^{\star} P<0.05$ compared with control. Results are means \pm S.E.M. for three to four independent experiments.

phospholipase, sPLA 2 IIA, rapidly within a few minutes and the effect persisted for up to $2-4 \mathrm{~h}$ (Figures $6 \mathrm{D}-6 \mathrm{G}$ ). In contrast, other $\mathrm{SPLA}_{2}$ isoforms previously identified within type II alveolar cells, including sPLA $\mathrm{X}_{2}$ and $\mathrm{SPLA}_{2} \mathrm{~V}$, were not secreted into the medium after agonist stimulation (results not shown) $[11,35,36]$. 


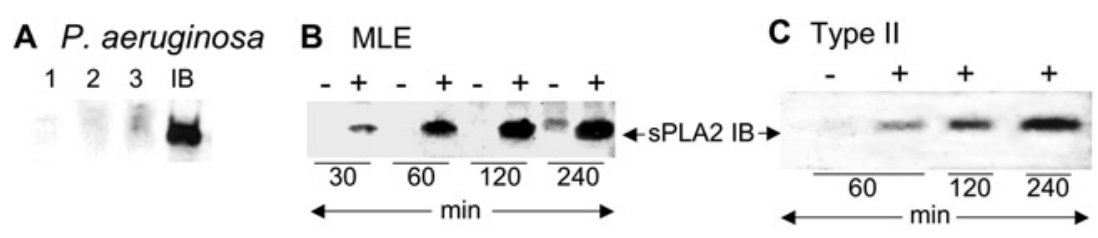

sPLA2 IB
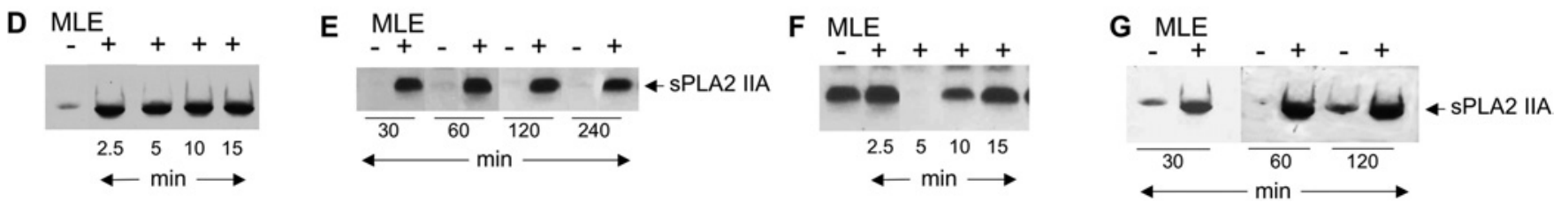

Figure 6 Ps. aeruginosa and $S P L A_{2}$ IB stimulate secretion of SPLA IIA and $S P L A_{2}$ IB in lung epithelia

(A) PS. aeruginosa was incubated in serum-free Hite's medium without antibiotics and in the absence of MLE- 12 cells for $2 \mathrm{~h}$. Proteins from $5 \mathrm{ml}$ of the medium were precipitated with $60 \%$ TCA and $1.5 \%$ sodium desoxycholate and applied on SDS/PAGE at various concentrations: lane 1, $50 \mu \mathrm{g}$; lane 2, $100 \mu \mathrm{g}$; lane 3, $150 \mu \mathrm{g}$. Gels were then processed for sPLA 2 IB immunoblotting. In lane 4 , bovine pancreas sPLA IB $(5 \mu \mathrm{g})$ was loaded on to the gel as a positive control. MLE-12 (B, D-G) and mouse primary type II cells $(\mathbf{C})$ were incubated with $(+)$ or without $(-)$ Ps. aeruginosa $(\mathrm{MOI}=5)(\mathbf{B}-\mathbf{E})$ or sPLA $\mathrm{IB}(100 \mu \mathrm{g} / \mathrm{ml})(\mathbf{F}, \mathbf{G})$ for various times, and medium and cell lysates were harvested. Proteins from $5 \mathrm{ml}$ of the medium was precipitated with $60 \% \mathrm{TCA}$ and $1.5 \%$ sodium desoxycholate, and immunoblot analysis was performed with anti-(SPLA $\mathrm{IB}$ ) and anti-(sPLA $\| \mathrm{IA})$ polyclonal antibodies. Bovine pancreas sPLA $(5 \mu \mathrm{g})$ was loaded on the gel as a positive control. Immunoblots are representative of three independent experiments.

\section{Pseudomonas aeruginosa}

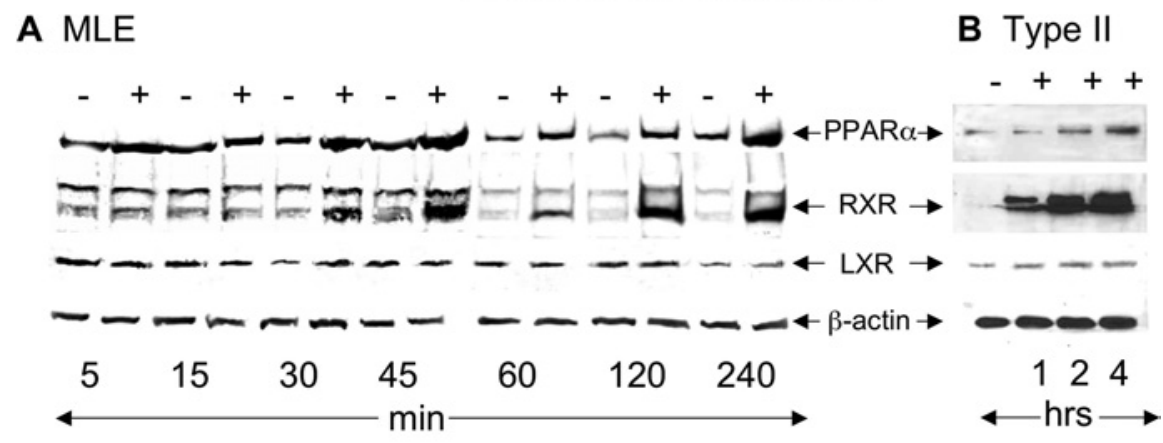

C

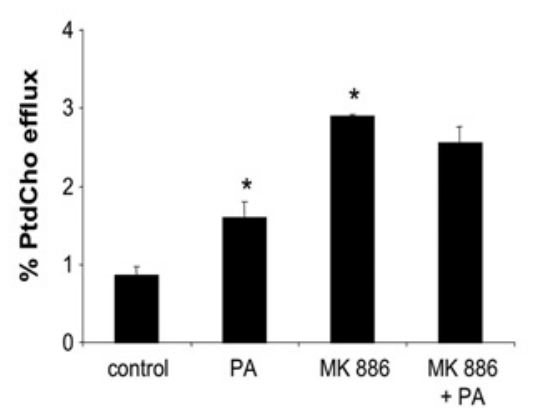

D

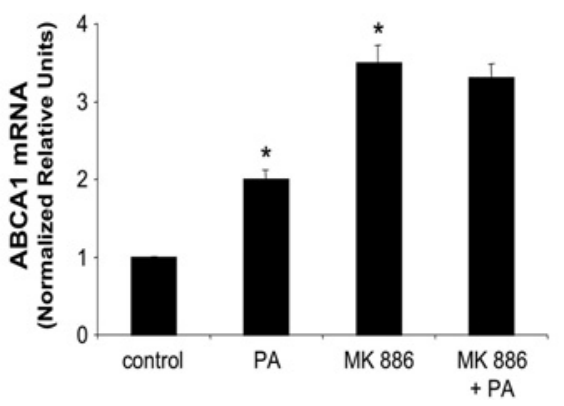

Figure 7 Ps. aeruginosa up-regulates PPAR $\alpha$ and RXR in MLE-12 cells

MLE-12 (A) and primary mouse type II (B) cells were incubated with $(+)$ or without $(-)$ PS. aeruginosa $(\mathrm{MOI}=5)$ for various times. Cell lysates were harvested, separated by SDS/10\% PAGE, and probed with anti-ABCA1, anti-PPAR $\alpha$, anti-RXR, anti-LXR and anti- $\beta$-actin antibodies. Relative protein levels in each experiment were detected by stripping one nitrocellulose membrane and re-probing with various antibodies. (C) Basolateral PtdCho efflux. MLE-12 cells were plated on transwells, labelled with [methyl- ${ }^{3} \mathrm{H}$ ]choline for $20 \mathrm{~h}$, incubated with MK 886 ( $5 \mu \mathrm{M}$ ) for $1 \mathrm{~h}$, and then infected with Ps. aeruginosa (MOI = 5) for $2 \mathrm{~h}$ using HDL $(20 \mu \mathrm{g} / \mathrm{ml})$ as a PtdCho acceptor. Basolateral medium and cells were harvested for PtdCho analysis. (D) MLE-12 cells were incubated with MK 886 and PS. aeruginosa as described above, and total RNA was harvested for ABCA1 mRNA analysis by real-time PCR using GAPDH transcripts as an internal control. ${ }^{\star} P<0.05$ compared with control. Results in histograms are means \pm S.E.M. for three independent experiments.

\section{Ps. aeruginosa and $S P L A_{2}$ IB increase ABCA1 expression via PPAR $\alpha-R X R$ heterodimerization}

$\mathrm{sPLA}_{2}$ IB and $\mathrm{sPLA} \mathrm{A}_{2}$ IIA can activate PPAR $\alpha$ [18]. PPAR $\alpha$ in turn heterodimerizes with RXR or LXR nuclear transcription factors that potently increase ABCA1 expression [37]. Thus we examined whether Ps. aeruginosa modulates heterodimerization with these receptor-binding partners. Immunoblot analysis of cells infected with Ps. aeruginosa (Figures 7A and 7B) revealed 3-4-fold induction of PPAR $\alpha$ from 30 min to $4 \mathrm{~h}$ in cells, and at $2 \mathrm{~h}$ and $4 \mathrm{~h}$ 
in primary mouse type II cells compared with control, as determined by densitometric analysis. In addition, Ps. aeruginosa also increased RXR expression from 2- to 20-fold co-ordinately with PPAR $\alpha$ stimulation without altering LXR or $\beta$-actin levels (Figures 7A and 7B).

Previously, it has been shown that activation of PPAR $\alpha$ reduced LXR-RXR formation, while LXR activation inhibited formation of PPAR $\alpha-\operatorname{RXR}[38,39]$. Thus heterodimeric association between individual dimeric receptor pairs can be manipulated that could potentially have an impact on ABCA1 expression [40]. To examine the functional relationships of these receptors to PtdCho efflux, cells were exposed to the PPAR $\alpha$ inhibitor MK 886 that surprisingly increased PtdCho efflux from cells independently of the effect of Ps. aeruginosa (Figure 7C). MK 886 also increased $A B C A 1$ mRNA levels (Figure 7D). Thus these data suggest that, although PPAR $\alpha$ might partake in ABCA1 activation in response to Ps. aeruginosa infection, it can act as a relative endogenous repressor or competitor of LXR-RXR complex formation that potently transactivates the $A B C A 1$ gene $[24,40,41]$. Moreover, the effects of Ps. aeruginosa on PPAR $\alpha$ and RXR expression were recapitulated with exogenous $\mathrm{SPLA}_{2} \mathrm{IB}$, which produced a $2-$ 4-fold increase in expression of these receptors over 5-240 min of analysis (Figure 8A). As with Ps. aeruginosa, PPAR $\alpha$ inhibition led to activation of PtdCho efflux and increased $A B C A l$ mRNA expression, a process that was not additive or synergistic with actions of $\mathrm{SPLA}_{2} \mathrm{IB}$ (Figures $8 \mathrm{~B}$ and $8 \mathrm{C}$ ). These data suggest that Ps. aeruginosa and $\mathrm{sLA}_{2} \mathrm{IB}$ can stimulate ABCA1 phospholipid export using similar mechanisms.

\section{Ps. aeruginosa and $s P L A_{2}$ IB stimulate PtdCho efflux via activation of $\mathrm{p} 44 / 42$ kinase}

The MAPK p44/42 phosphorylates PPAR $\alpha$ and increases its expression [42]. Indeed, Ps. aeruginosa and sPLA 2 IB each triggered an increase in p44/42 activity in cells (Figures 9A and 9C), which was determined to be $2-3$-fold by densitometric analysis (results not shown). These changes in p44/42 activity were observed in response to agonist stimulation within $2.5-5 \mathrm{~min}$. Furthermore, PD98059, an inhibitor of MEK1, a kinase upstream of p44/42 kinase, attenuated effects of Ps. aeruginosa (Figure 9B) and sPLA $\mathrm{AB}_{2}$ (Figure 9D) on PtdCho efflux in lung epithelium.

Transfection of cells with constitutively active MEK1 plasmid induced PPAR $\alpha, \mathrm{RXR}$ and ABCA1 expression without altering $\beta$-actin levels (Figure 9E). These data suggest that activation of $\mathrm{p} 44 / \mathrm{p} 42$ kinase stimulates ABCA1 expression via PPAR $\alpha-\mathrm{RXR}$ heterodimerization.

\section{Ps. aeruginosa and $S P L A_{2}$ IB transcriptionally activate the $A B C A 1$ gene in lung epithelia}

MLE-12 cells were transfected with various $A B C A 1$ promoter constructs followed by exposure to Ps. aeruginosa or $\mathrm{SPLA}_{2} \mathrm{IB}$ (Figure 10A). Ps. aeruginosa and $\mathrm{SPLA}_{2}$ IB each produced a modest stimulatory effect on $A B C A l$ promoter activity using various $\mathrm{ABCA} 1$ constructs relative to an empty reporter construct (Figures 10B and 10C). The $A B C A l$ gene is activated by an RXRLXR-dependent pathway via binding of this heterodimer to a specific DR-4 element located within the proximal 5'-flanking region of the gene. Furthermore, PPAR $\alpha-\mathrm{RXR}$ heterodimers bind to a DR-1 (direct repeat 1 ) element. ABCA $1_{-949 /+274}$ harbours only a partial DR-1 sequence and an intact DR-4 locus. Deletion of DR-1 half sites in $\mathrm{ABCA} 1_{-949 /+274}, \mathrm{ABCA} 1_{-205 /+274}$ and ABCA $1_{-77 /+274}$ did not attenuate promoter activation by $P S$. aeruginosa and $\mathrm{sPLA}_{2}$ IB (Figures $10 \mathrm{~B}$ and 10C). In contrast,

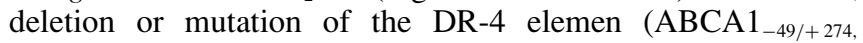
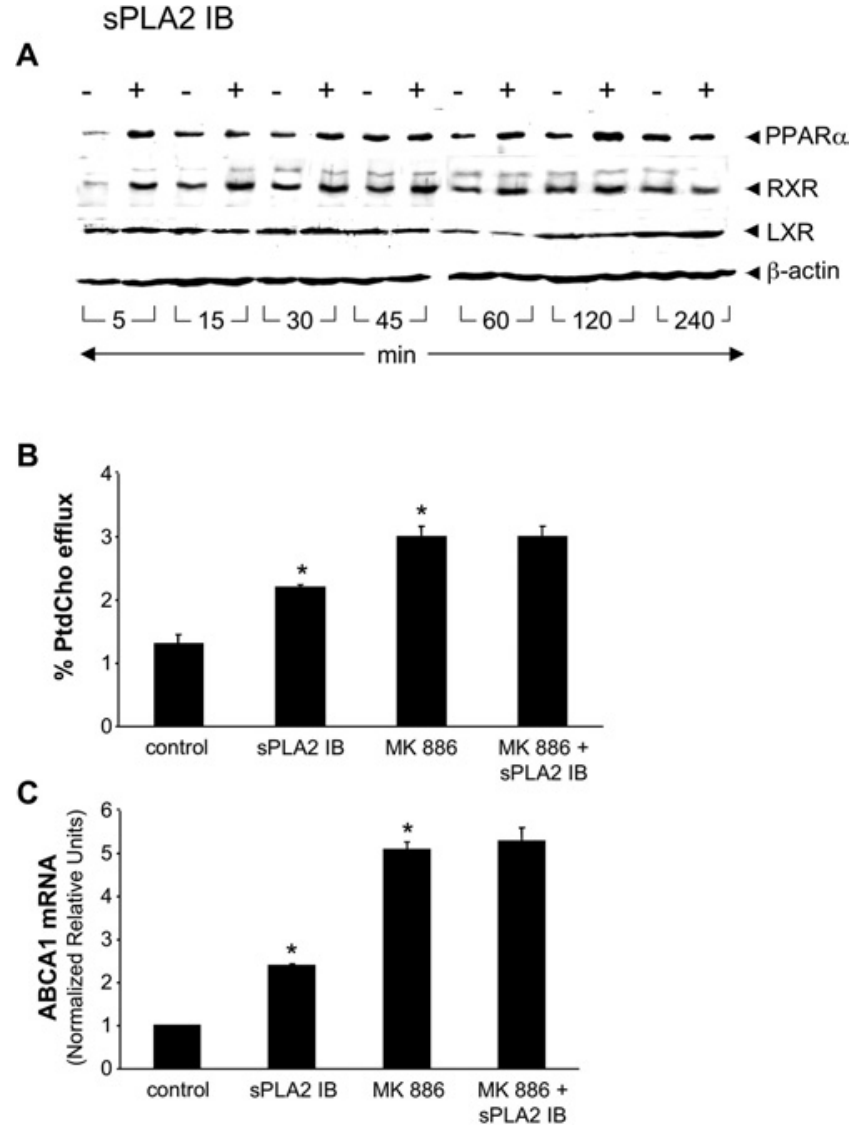

Figure 8 sPLA 2 IB up-regulates PPAR $\alpha$ and RXR in MLE-12 cells

(A) MLE-12 cells were incubated with (+) or without (-) sPLA 1 B (100 $\mu \mathrm{g} / \mathrm{ml})$ for various times. Cell lysates were harvested, separated by SDS/10\% PAGE, and probed with anti-ABCA1, anti-PPAR $\alpha$, anti-RXR, anti-LXR and anti- $\beta$-actin antibodies. Relative protein levels in each experiment were detected by stripping one nitrocellulose membrane and reprobing with various antibodies. (B) Basolateral PtdCho efflux. MLE-12 cells were plated on transwells, labelled with [methyl- ${ }^{3} \mathrm{H}$ ]choline for $20 \mathrm{~h}$, incubated with MK $886(5 \mu \mathrm{M})$ for $1 \mathrm{~h}$ and then exposed to $\mathrm{SPLA}_{2}$ IB (100 $\mu \mathrm{g} / \mathrm{ml})$ for $2 \mathrm{~h}$ using HDL $(20 \mu \mathrm{g} / \mathrm{ml})$ as a PtdCho acceptor. Basolateral medium and cells were harvested for PtdCho analysis. (C) MLE-12 cells were incubated with MK 886 and $\mathrm{SPLA} \mathrm{A}_{2} \mathrm{IB}$ as described above, and total RNA was harvested for $A B C A 1 \mathrm{mRNA}$ analysis by real-time PCR using GAPDH transcripts as an internal control. ${ }^{*} P<0.05$ compared with control. Results in histograms are means \pm S.E.M. for three independent experiments.

ABCA1 $-77 \mathrm{mut} /+274$ ) totally abrogated $P$ s. aeruginosa- and $\mathrm{SPLA}_{2}$ IB-mediated $\mathrm{ABCA} 1$ promoter activation (Figures 10B and 10C). These observations suggest that $P s$. aeruginosa and $\mathrm{SPLA}_{2} \mathrm{IB}$ trigger receptor heterodimerization that transactivates the $A B C A 1$ gene via DR-4 binding.

\section{DISCUSSION}

Bacterial infection has been shown to accelerate phospholipid hydrolysis within various systems, but little is known regarding the effects of these pathogens on lipid transport. The new data from the present study indicate that (i) Ps. aeruginosa triggers basolateral export of the major eukaryotic phospholipid, PtdCho, from lung epithelia, (ii) this effect is mediated, in part, by the ATP-dependent pump, ABCA1, (iii) Ps. aeruginosa increases ABCA1 expression by increasing gene transcription, and (iv) $P s$. aeruginosa up-regulates expression of a distinct array of signalling molecules known to be involved in ABCA1 expression. These effects of $P$ s. aeruginosa are also observed with $\mathrm{sLA}_{2} \mathrm{IB}$, a key inflammatory mediator involved in phospholipid catabolism and 


\section{P. aeruginosa}

A

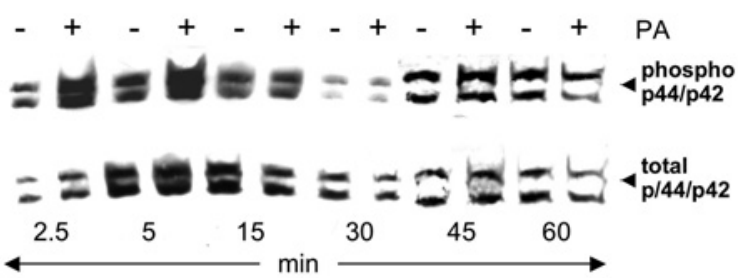

B

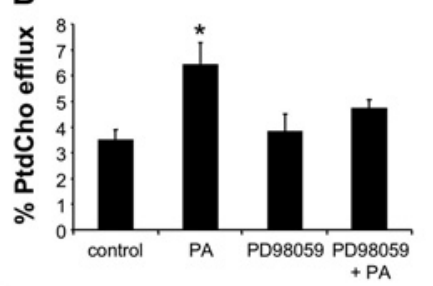

SPLA2 IB

C

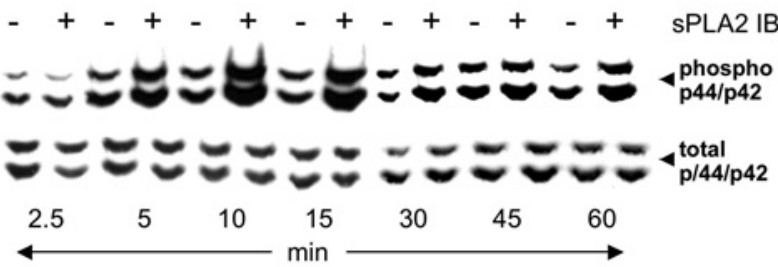

E

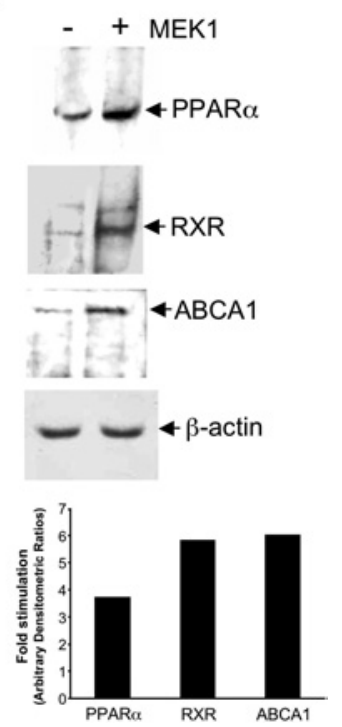

Figure 9 s. aeruginosa and $S P L A_{2}$ IB activate p44/p42 kinase

MLE-12 cells were exposed to PS. aeruginosa $(\mathrm{MOI}=5)(\mathrm{PA})(\mathbf{A})$ or $\mathrm{sPLA} \mathrm{A}_{2} \mathrm{IB}(100 \mu \mathrm{g} / \mathrm{ml})(\mathbf{C})$ for various times, and cell lysates were harvested and processed for immunoblotting. Nitrocellulose membranes were probed with antibodies against phosphorylated (active) and total p44/p42 isoforms. (B) Basolateral PtdCho export. MLE-12 cells were labelled for $20 \mathrm{~h}$ with [methyl- $\left.{ }^{3} \mathrm{H}\right]$ choline, incubated for $1 \mathrm{~h}$ with PD98059 $(10 \mu \mathrm{M})$ and subsequently exposed for $2 \mathrm{~h}$ to Ps. aeruginosa $(\mathbf{B})$ or sPLA IB (D). Medium was harvested and processed for PtdCho analysis. (E) MLE-12 cells were transfected with a MEK1 plasmid $(4 \mu \mathrm{g})$ overnight, and the next day harvested and processed for immunoblot analysis using anti-PPAR $\alpha$, anti-RXR, anti-ABCA1 and anti- $\beta$-actin antibodies. ${ }^{*} P<0.05$ compared with control. Results in histograms are means \pm S.E.M. for three independent experiments.

the innate host response [43]. Indeed, $\mathrm{SPLA}_{2} \mathrm{IB}$ is released from MLE-12 cell in response to Ps. aeruginosa infection (Figure 6). The data as a whole suggest that $P$ s. aeruginosa infection exploits a phospholipid-trafficking mechanism, catalysed by ABCA1, as a means to deplete the intracellular pool of PtdCho. Because alveolar type II epithelial cells utilize PtdCho for new cell membrane formation and surfactant biosynthesis, these results expand on the pathobiology of bacterial infections as it relates to properties that intrinsically link to cellular viability. The secretion of $\mathrm{SPLA}_{2} \mathrm{~s}$ by alveolar epithelia after infection as shown in the present study is intriguing, and may initially represent an attempt by host cells to degrade bacterial phospholipids $[43,44]$. However, $\mathrm{SPLA}_{2}$ IB secretion by epithelia after $P$ s. aeruginosa infection may also facilitate hydrolysis of extracellular surfactant PtdCho or trigger signalling events that eventually lead to the demise of the type II cell by altering phospholipid homoeostasis.

Previous studies have identified ABCA1 as a lipid sensor that might serve to help maintain the delicate balance of phospholipids within lung epithelium [28-30]. By using two different proinflammatory agonists, $P$ s. aeruginosa and exogenous $\mathrm{SPLA}_{2} \mathrm{IB}$ each increased PtdCho export via a basolateral route in epithelial cells. These physiological changes in response to pro-inflammatory agonist stimulation were associated with increases in ABCA1 protein and mRNA levels and transactivation of the $A B C A 1$ promoter via a DR-4 locus-dependent mechanism. These effects of Ps. aeruginosa resemble those of LPS that either increases or decreases $A B C A 1$ mRNAs in other systems, suggesting that effects of the bacterium may be due partly to LPS components. However, LPS did not trigger ABCA1-mediated efflux in our studies (Figure 2D). Phospholipid efflux after bacterial infection was abolished further after pharmacological inhibition of ABCA1 and not observed in Tangier disease cells, in support of a causal role for ABCA1 in mediating effects of Ps. aeruginosa. Furthermore, $P s$. aeruginosa increases in PtdCho efflux were not observed in $\mathrm{H} 441$ and $\mathrm{CaCo}-2$ cells, recapitulated with related Gramnegative pathogens, nor did Ps. aeruginosa increase ABCG1 and ABCG5 expression or stimulate lyso-PtdCho or SM export. The lack of export of SM by the bacterium may be an attempt to conserve cellular levels of this lipid, as Ps. aeruginosa triggers SM hydrolysis within membrane rafts, an event that appears to be essential for the cytokine and apoptotic response in infected cells [45]. Taken together, these results indicate that Ps. aeruginosa effects on lipid trafficking in lung epithelia appear to be fairly specific with regard to the nature of lipid exported in cells.

A new observation from this study is that Ps. aeruginosa stimulates secretion of immunoreactive $\mathrm{SPLA}_{2} \mathrm{IB}$ and $\mathrm{SPLA}_{2}$ IIA, rather than $\mathrm{sPLA}_{2} \mathrm{~V}$ and $\mathrm{sPLA}_{2} \mathrm{X}$, from distal lung epithelia. The mRNAs for these phospholipases are all detected in the lung, but it appears that $\mathrm{SPLA}_{2}$ IIA serves as a major effector in acute lung injury [9]. However, sPLA $\mathrm{A}_{2}$ IIA and $\mathrm{sPLA}_{2} \mathrm{IB}$, unlike $\mathrm{sPLA}_{2} \mathrm{~V}$ and $\mathrm{SPLA}_{2} \mathrm{X}$, exhibit different substrate requirements, in that they have higher activities against phosphatidylglycerol with little preference for PtdCho [11]. Phosphatidylglycerol does provide some surface-tension-lowering activity and, with PtdCho, may be important in maintaining lung stability; however, this phospholipid is a minor component of surfactant $[11,46]$. Thus $\mathrm{sPLA}_{2}$ IB and $\mathrm{sPLA}_{2}$ IIA release after $P$ s. aeruginosa infection might reduce surfactant by inciting other inflammatory pathways distinct from their enzymatic properties on surfactant phospholipids. As shown in the present study, sPLA ${ }_{2}$ IB stimulation of basal PtdCho export in combination with sPLA $\mathrm{PL}_{2}$ IIA activity might be one mechanism whereby these lipases accentuate pulmonary injury; this could occur by reducing phospholipids destined for secretion as part of surfactant or ultimately directed into alveolar membranes. Both lipases were released rapidly (within $30 \mathrm{~min}$ ) from epithelia (Figure 6) after bacterial infection, but the kinetics of Ps. aeruginosa compared with $\mathrm{SPLA}_{2} \mathrm{IB}$ differed somewhat with regard to effects on ABCA1 protein. Maximal effects of 


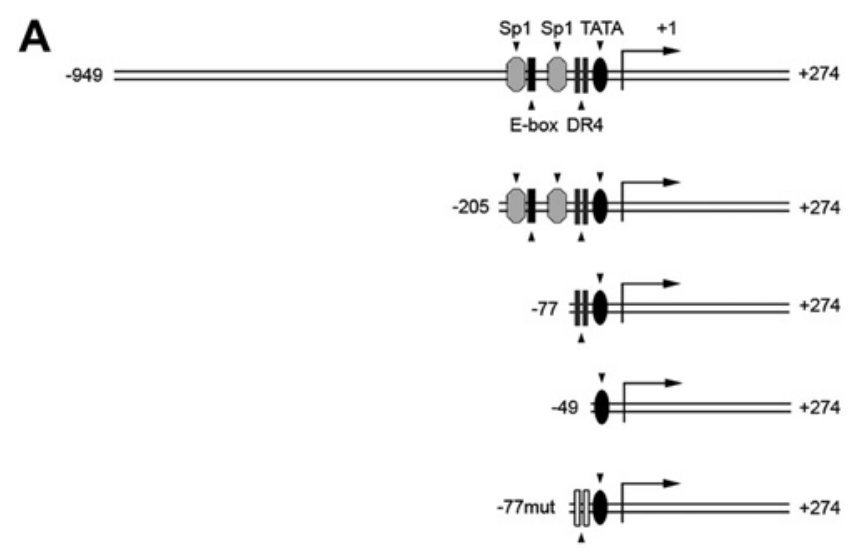

B

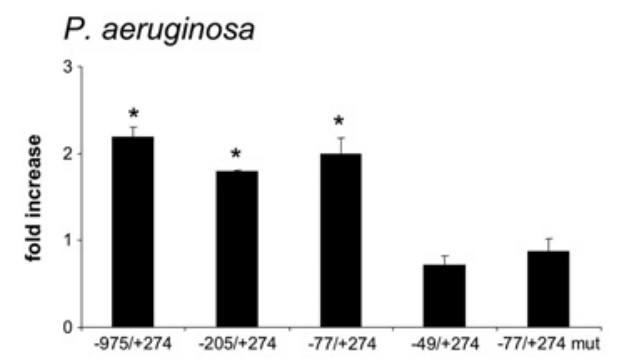

C

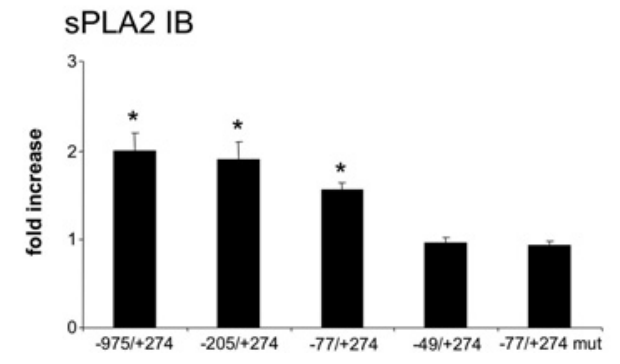

Figure $10 P s$. aeruginosa and $S P L A_{2} I B$ increase $A B C A 1$ promoter activity

(A) Schematic illustration of $A B C A 1$ promoter constructs. Three constructs contain a DR-4 element $(-949 /+274,-205 /+274$ and $-77 /+274)$, one lacks this element $(-49 /+274)$, and one contains a mutation within DR4 ( $-77 /+274$ mut). (B, C) Cells were co-transfected with these $A B C A 1$ promoter reporters and $\mathrm{pSV}-\beta$-galactosidase for $2-4 \mathrm{~h}$ before exposure to Ps. aeruginosa $(\mathrm{MOI}=5)(\mathbf{B})$ or PLA $\mathrm{IB}(100 \mu \mathrm{g} / \mathrm{ml})(\mathbf{C})$ for $2 \mathrm{~h}$. Lysates were assayed for luciferase and $\beta$-galactosidase activities. Results are means \pm S.E.M. fold increases of luciferase/ $\beta$-galactosidase activities in the cells exposed to Ps. aeruginosa and $S P L A_{2} I B$ compared with control for three independent experiments. ${ }^{*} P<0.05$ compared with control.

Ps. aeruginosa on induction of ABCA1 levels were observed within $1 \mathrm{~h}$, whereas sPLA $\mathrm{IB}_{2}$ optimally increased the transporter after $4 \mathrm{~h}$ (Figure 3 ). These data suggest that other yet unidentified factors associated with intact bacteria may synergize to more rapidly stimulate $A B C A l$ gene transcription.

$P$ s. aeruginosa and $\mathrm{SPLA}_{2} \mathrm{IB}$ each triggered $\mathrm{PPAR} \alpha$ and $\mathrm{RXR}$ activation without affecting LXR expression in lung epithelia. $\operatorname{PPAR} \alpha, \mathrm{RXR}$ and LXR serve as key transcription factors that regulate $A B C A 1$ expression, resulting in enhanced cholesterol efflux [47]. sPLA $\mathrm{A}_{2}$ IB also triggers sPLA $\mathrm{A}_{2}$ IIA release via an autocrine loop involving PPAR $\alpha$ and induces PPAR $\alpha-\mathrm{RXR}$ complex formation in mesanglial cells [18]. Of note, MJ33 and pyrrolidin1 , inhibitors of $\mathrm{SPLA}_{2} \mathrm{IB}$ and $\mathrm{CPLA}_{2}$ activities respectively, did not attenuate the effect of Ps. aeruginosa or sPLA $\mathrm{P}_{2}$ IB on PtdCho efflux in our experiments (results not shown). Thus it is possible that $\mathrm{SPLA}_{2}$ IB exerts its signalling effects on this ABCA1 pathway via transmembrane signalling through binding to membrane re-

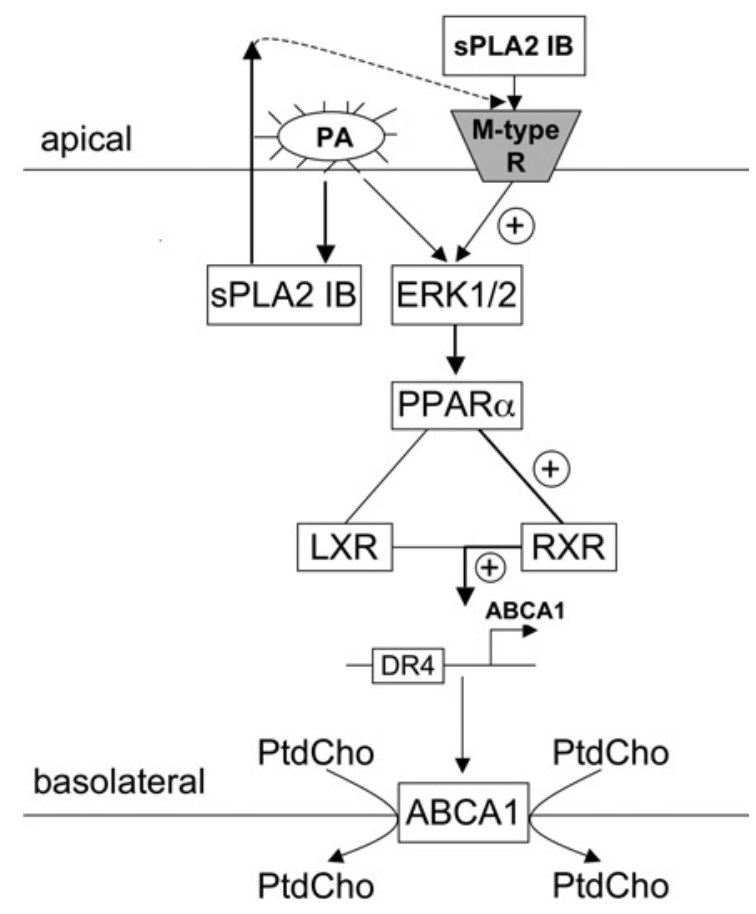

Figure 11 Mechanisms of ABCA1 activation by Ps. aeruginosa and exogenous SPLA 2 IB

The solid lines indicate known pathways, the broken lines indicate putative mechanisms, and the thick solid lines indicate mechanisms discussed in the present paper.

ceptors independently of its catalytic activity, as has been suggested previously [18].

Although Ps. aeruginosa or $\operatorname{sPLA}_{2}$ IB increased $\operatorname{PPAR} \alpha$ and RXR expression, it is also notable that MK 886, a PPAR $\alpha$ inhibitor, increases ABCA1 expression and phospholipid efflux when added to cells alone (Figures 7C, 7D, 8B and 8C). This apparent inconsistency can be explained by competition for heterodimeric association by individual receptors. For example, LXR-PPAR $\alpha$ heterodimerization leads to reduction of $\operatorname{PPAR} \alpha-\mathrm{RXR}$ formation, and PPAR $\alpha$ activation reduces LXR-RXR heterodimerization $[38,39]$. Such overlapping and competitive transcriptional programs involving PPAR $\alpha, \mathrm{RXR}$ and LXR were also demonstrated in mouse liver [40]. Our data are consistent with these results, where, depending on the relative abundance of each heterodimeric pair, PPAR $\alpha$ could serve as an endogenous repressor of LXRRXR heterodimer formation. Thus inhibition of PPAR $\alpha$ in our experiments by MK 886 may induce heterodimerization of LXR$\mathrm{RXR}$, the most potent activator of $A B C A l$ gene transcription $[24,41]$.

Finally, Ps. aeruginosa or sPLA 2 IB rapidly activated p44/ 42 MAPK, MEK1 induced PPAR $\alpha-$ RXR and ABCA1 expression, and effects of physiological agonists were blocked using PD98059. These results strongly implicate ERKs as upstream regulators of the ABCA1 efflux pathway. Indeed, Ps. aeruginosa activates p44/p42 kinase in airway epithelia, and PPAR $\alpha$ is activated by $\mathrm{p} 44 / 42$ MAPK in response to insulin via phosphorylation of its N-terminus [42,48]. Moreover, $\mathrm{SPLA}_{2} \mathrm{IB}$, via binding to its receptor, dramatically induces p44/42 MAPK activation in human neutrophils $[49,50]$. As a whole, these observations suggest a Ps. aeruginosa $\rightarrow \mathrm{sPLA}_{2} \quad \mathrm{IB} \rightarrow \mathrm{p} 44 / \mathrm{p} 42$ kinases $\rightarrow$ $\mathrm{PPAR} \alpha / \mathrm{RXR} \rightarrow \mathrm{ABCA} 1$ pathway (Figure 11). According to this scheme, Ps. aeruginosa induces $\mathrm{sPLA}_{2}$ IB secretion from alveolar epithelium. $\mathrm{sPLA}_{2} \mathrm{IB}$ via binding to its membrane receptor 
activates p44/p42 kinases that phosphorylate and activate PPAR $\alpha$. PPAR $\alpha$ heterodimerizes with RXR and activates ABCA1 via binding of this heterodimer to a DR-4 element within the $A B C A I$ promoter. Thus $P$ s. aeruginosa may impair lung function via induction of basolateral ABCA1-mediated surfactant PtdCho export in murine alveolar epithelium. The results do not exclude effects of Ps. aeruginosa that are independent of $\mathrm{sPLA}_{2}$. Future studies may involve investigating this pathway using animal models of bacterial infection where secretory phospholipases might emerge as physiologically relevant molecular targets for therapeutic intervention in inflammatory lung injury.

We thank Dr Timothy Yahr for providing PA103 and Dr Florita Henderson for her assistance with bacterial preparations. This work was supported by a Merit Review Award, Department of Veterans Affairs, and NIH (National Institutes of Health) R01 Grants HL081784, HL068135 and HL080229 (to R. K. M.).

\section{REFERENCES}

1 Sadikot, R. T., Blackwell, T. S., Christman, J. W. and Prince, A. S. (2005) Pathogen-host interactions in Pseudomonas aeruginosa pneumonia. Am. J. Respir. Crit. Care Med. 171, 1209-1223

2 Hauser, A. R., Cobb, E., Bodi, M., Mariscal, D., Valles, J., Engel, J. N. and Rello, J. (2002) Type III protein secretion is associated with poor clinical outcomes in patients with ventilator-associated pneumonia caused by Pseudomonas aeruginosa. Crit. Care Med. 30, $521-528$

3 Rabin, S. D. and Hauser, A. R. (2003) Pseudomonas aeruginosa ExoU, a toxin transported by the type III secretion system, kills Saccharomyces cerevisiae. Infect. Immun. 71, 4144-4150

4 Arbibe, L., Vial, D., Rosinski-Chupin, I., Havet, N., Huerre, M., Vargaftig, B. B. and Touqui, L. (1997) Endotoxin induces expression of type II phospholipase $A_{2}$ in macrophages during acute lung injury in guinea pigs: involvement of TNF- $\alpha$ in lipopolysaccharide-induced type II phospholipase $\mathrm{A}_{2}$ synthesis. J. Immunol. 159, 391-400

5 Vial, D., Senorale-Pose, M., Havet, N., Molio, L., Vargaftig, B. B. and Touqui, L. (1995) Expression of the type-II phospholipase $\mathrm{A}_{2}$ in alveolar macrophages: down-regulation by an inflammatory signal. J. Biol. Chem. 270, 17327-17332

6 Garrity-Ryan, L., Kazmierczak, B., Kowal, R., Comolli, J., Hauser, A. and Engel, J. N. (2000) The arginine finger domain of ExoT contributes to actin cytoskeleton disruption and inhibition of internalization of Pseudomonas aeruginosa by epithelial cells and macrophages. Infect. Immun. 68, 7100-7113

7 Chitko-McKown, C. G., Chapes, S. K., Brown, R. E., Phillips, R. M., McKown, R. D. and Blecha, F. (1991) Porcine alveolar and pulmonary intravascular macrophages: comparison of immune functions. J. Leukocyte Biol. 50, 364-372

8 Phillips, R. M., Six, D. A., Dennis, E. A. and Ghosh, P. (2003) In vivo phospholipase activity of the Pseudomonas aeruginosa cytotoxin ExoU and protection of mammalian cells with phospholipase $A_{2}$ inhibitors. J. Biol. Chem. 278, 41326-41332

9 Attalah, H. L., Wu, Y., Alaoui-El-Azher, M., Thouron, F., Koumanov, K., Wolf, C., Brochard, L., Harf, A., Delclaux, C. and Touqui, L. (2003) Induction of type-IIA secretory phospholipase $A_{2}$ in animal models of acute lung injury. Eur. Respir. J. 21, 1040-1045

10 Gobran, L. I. and Rooney, S. A. (2004) Pulmonary surfactant secretion in briefly cultured mouse type II cells. Am. J. Physiol Lung Cell. Mol. Physiol. 286, L331-L336

11 Hanasaki, K. and Arita, H. (1999) Biological and pathological functions of phospholipase $\mathrm{A}_{2}$ receptor. Arch. Biochem. Biophys. 372, 215-223

12 Touqui, L. and Arbibe, L. (1999) A role for phospholipase $A_{2}$ in ARDS pathogenesis. Mol. Med. Today 5, 244-249

13 Touqui, L. and Alaoui-El-Azher, M. (2001) Mammalian secreted phospholipases $A_{2}$ and their pathophysiological significance in inflammatory diseases. Curr. Mol. Med. 1, 739-754

14 Touqui, L. and Wu, Y. Z. (2003) Interaction of secreted phospholipase $A_{2}$ and pulmonary surfactant and its pathophysiological relevance in acute respiratory distress syndrome. Acta Pharmacol. Sin. 24, 1292-1296

15 Offer, S., Yedgar, S., Schwob, 0., Krimsky, M., Bibi, H., Eliraz, A., Madar, Z. and Shoseyov, D. (2005) Negative feedback between secretory and cytosolic phospholipase $A_{2}$ and their opposing roles in ovalbumin-induced bronchoconstriction in rats. Am. J. Physiol. Lung Cell. Mol. Physiol. 288, L523-L529

16 Nevalainen, T. J., Hietaranta, A. J. and Gronroos, J. M. (1999) Phospholipase $A_{2}$ in acute pancreatitis: new biochemical and pathological aspects. Hepatogastroenterology $\mathbf{4 6}$, 2731-2735
17 Cupillard, L., Mulherkar, R., Gomez, N., Kadam, S., Valentin, E., Lazdunski, M. and Lambeau, G. (1999) Both group IB and group IIA secreted phospholipases $A_{2}$ are natural ligands of the mouse 180-kDa M-type receptor. J. Biol. Chem. 274, 7043-7051

18 Beck, S., Lambeau, G., Scholz-Pedretti, K., Gelb, M. H., Janssen, M. J., Edwards, S. H., Wilton, D. C., Pfeilschifter, J. and Kaszkin, M. (2003) Potentiation of tumor necrosis factor $\alpha$-induced secreted phospholipase $\mathrm{A}_{2}(\mathrm{SPLA})$-IIA expression in mesangial cells by an autocrine loop involving sPLA $\mathrm{A}_{2}$ and peroxisome proliferator-activated receptor $\alpha$ activation. J. Biol. Chem. 278, 29799-29812

19 Daynes, R. A. and Jones, D. C. (2002) Emerging roles of PPARs in inflammation and immunity. Nat. Rev. Immunol. 2, 748-759

20 Specty, 0., Pageaux, J. F., Dauca, M., Lagarde, M., Laugier, C. and Fayard, J. M. (2001) Control of cell proliferation via transduction of $s P L A_{2}-I$ activity and possible PPAR activation at the nuclear level. FEBS Lett. 490, 88-92

21 Duval, C., Fruchart, J. C. and Staels, B. (2004) PPAR $\alpha$, fibrates, lipid metabolism and inflammation. Arch. Mal. Coeur Vaiss. 97, 665-672

22 Francis, G. A., Fayard, E., Picard, F. and Auwerx, J. (2003) Nuclear receptors and the control of metabolism. Annu. Rev. Physiol. 65, 261-311

23 Li, A. C. and Palinski, W. (2006) Peroxisome proliferator-activated receptors: how their effects on macrophages can lead to the development of a new drug therapy against atherosclerosis. Annu. Rev. Pharmacol. Toxicol. 46, 1-39

24 Costet, P., Luo, Y., Wang, N. and Tall, A. R. (2000) Sterol-dependent transactivation of the $\mathrm{ABC1}$ promoter by the liver $X$ receptor/retinoid $X$ receptor. J. Biol. Chem. $\mathbf{2 7 5}$ 28240-28245

25 Repa, J. J., Turley, S. D., Lobaccaro, J. A., Medina, J., Li, L., Lustig, K., Shan, B., Heyman, R. A., Dietschy, J. M. and Mangelsdorf, D. J. (2000) Regulation of absorption and $A B C 1$-mediated efflux of cholesterol by RXR heterodimers. Science $\mathbf{2 8 9}$, 1524-1529

26 Chen, W., Sun, Y., Welch, C., Gorelik, A., Leventhal, A. R., Tabas, I. and Tall, A. R. (2001) Preferential ATP-binding cassette transporter A1-mediated cholesterol efflux from late endosomes/lysosomes. J. Biol. Chem. 276, 43564-43569

27 Venkateswaran, A., Laffitte, B. A., Joseph, S. B., Mak, P. A., Wilpitz, D. C., Edwards, P. A. and Tontonoz, P. (2000) Control of cellular cholesterol efflux by the nuclear oxysterol receptor LXR $\alpha$. Proc. Natl. Acad. Sci. U.S.A. 97, 12097-12102

28 Agassandian, M., Mathur, S. N., Zhou, J., Field, F. J. and Mallampalli, R. K. (2004) Oxysterols trigger ABCA1-mediated basolateral surfactant efflux. Am. J. Respir. Cell Mol. Biol. 31, 227-233

29 Bates, S. R., Tao, J. Q., Collins, H. L., Francone, O. L. and Rothblat, G. H. (2005) Pulmonary abnormalities due to ABCA1 deficiency in mice. Am. J. Physiol. Lung Cell. Mol. Physiol. 289, L980-L989

30 Zhou, J., You, Y., Ryan, A. J. and Mallampalli, R. K. (2004) Upregulation of surfactant synthesis triggers ABCA1-mediated basolateral phospholipid efflux. J. Lipid Res. 45 , 1758-1767

31 Hartl, D. and Griese, M. (2005) Interstitial lung disease in children: genetic background and associated phenotypes. Respir. Res. 6, 32

32 Zhou, J., Wu, Y., Henderson, F., McCoy, D. M., Salome, R. G., McGowan, S. E. and Mallampalli, R. K. (2006) Adenoviral gene transfer of a mutant surfactant enzyme ameliorates pseudomonas-induced lung injury. Gene Ther. 13, 974-985

33 Mallampalli, R. K., Peterson, E. J., Carter, A. B., Salome, R. G., Mathur, S. N. and Koretzky, G. A. (1999) TNF- $\alpha$ increases ceramide without inducing apoptosis in alveolar type II epithelial cells. Am. J. Physiol. 276, L481-L490

34 Rosner, B. A. (1996) Measurement error models for ordinal exposure variables measured with error. Stat. Med. 15, 293-303

35 Hanasaki, K. and Arita, H. (2003) Biological functions of group X secretory PLA . Adv. Exp. Med. Biol. 525, 93-96

36 Mitsuishi, M., Masuda, S., Kudo, I. and Murakami, M. (2006) Group V and X secretory phospholipase $A_{2}$ prevents adenoviral infection in mammalian cells. Biochem. J. 393, 97-106

37 Chinetti, G., Lestavel, S., Bocher, V., Remaley, A. T., Neve, B., Torra, I. P., Teissier, E., Minnich, A., Jaye, M., Duverger, N. et al. (2001) PPAR- $\alpha$ and PPAR- $\gamma$ activators induce cholesterol removal from human macrophage foam cells through stimulation of the ABCA1 pathway. Nat. Med. 7, 53-58

38 Ide, T., Shimano, H., Yoshikawa, T., Yahagi, N., Amemiya-Kudo, M., Matsuzaka, T., Nakakuki, M., Yatoh, S., lizuka, Y., Tomita, S. et al. (2003) Cross-talk between peroxisome proliferator-activated receptor (PPAR) $\alpha$ and liver $X$ receptor (LXR) in nutritional regulation of fatty acid metabolism. II. LXRs suppress lipid degradation gene promoters through inhibition of PPAR signaling. Mol. Endocrinol. 17, 1255-1267

39 Yoshikawa, T., Ide, T., Shimano, H., Yahagi, N., Amemiya-Kudo, M., Matsuzaka, T., Yatoh, S., Kitamine, T., Okazaki, H. and Tamura, Y. (2003) Cross-talk between peroxisome proliferator-activated receptor (PPAR) $\alpha$ and liver $X$ receptor (LXR) in nutritional regulation of fatty acid metabolism. I. PPARs suppress sterol regulatory element binding protein-1c promoter through inhibition of LXR signaling. Mol. Endocrinol. 17, 1240-1254 
40 Anderson, S. P., Dunn, C., Laughter, A., Yoon, L., Swanson, C., Stulnig, T. M., Steffensen, K. R., Chandraratna, R. A., Gustafsson, J.-Å. and Corton, J. C. (2004) Overlapping transcriptional programs regulated by the nuclear receptors peroxisome proliferatoractivated receptor $\alpha$, retinoid $\mathrm{X}$ receptor, and liver $\mathrm{X}$ receptor in mouse liver. Mol. Pharmacol. 66, 1440-1452

41 Costet, P., Lalanne, F., Gerbod-Giannone, M. C., Molina, J. R., Fu, X., Lund, E. G., Gudas, L. J. and Tall, A. R. (2003) Retinoic acid receptor-mediated induction of ABCA1 in macrophages. Mol. Cell. Biol. 23, 7756-7766

42 Juge-Aubry, C. E., Hammar, E., Siegrist-Kaiser, C., Pernin, A., Takeshita, A., Chin, W. W., Burger, A. G. and Meier, C. A. (1999) Regulation of the transcriptional activity of the peroxisome proliferator-activated receptor $\alpha$ by phosphorylation of a ligand-independent trans-activating domain. J. Biol. Chem. 274, 10505-10510

43 Dubouix, A., Campanac, C., Fauvel, J., Simon, M. F., Salles, J. P., Roques, C., Chap, H. and Marty, N. (2003) Bactericidal properties of group Ila secreted phospholipase $\mathrm{A}_{2}$ against Pseudomonas aeruginosa clinical isolates. J. Med. Microbiol. 52, 1039-1045

44 Koduri, R. S., Gronroos, J. O., Laine, V. J., Le Calvez, C., Lambeau, G., Nevalainen, T. J. and Gelb, M. H. (2002) Bactericidal properties of human and murine groups I, II, V, X, and XII secreted phospholipases $A_{2}$. J. Biol. Chem. 277, 5849-5857

Received 5 September 2006/2 January 2007; accepted 16 January 2007

Published as BJ Immediate Publication 16 January 2007, doi:10.1042/BJ20061364
45 Grassme, H., Jendrossek, V., Riehle, A., von Kurthy, G., Berger, J., Schwarz, H., Weller, M., Kolesnick, R. and Gulbins, E. (2003) Host defense against Pseudomonas aeruginosa requires ceramide-rich membrane rafts. Nat. Med. 9, 322-330

46 Hite, R. D., Seeds, M. C., Bowton, D. L., Grier, B. L., Safta, A. M., Balkrishnan, R., Waite, B. M. and Bass, D. A. (2005) Surfactant phospholipid changes after antigen challenge: a role for phosphatidylglycerol in dysfunction. Am. J. Physiol. Lung Cell. Mol. Physiol. 288, L610-L617

47 Wang, N., Silver, D. L., Thiele, C. and Tall, A. R. (2001) ATP-binding cassette transporter A1 (ABCA1) functions as a cholesterol efflux regulatory protein. J. Biol. Chem. $\mathbf{2 7 6}$ 23742-23747

48 Blanquart, C., Mansouri, R., Fruchart, J. C., Staels, B. and Glineur, C. (2004) Different ways to regulate the PPAR $\alpha$ stability. Biochem. Biophys. Res. Commun. 319, 663-670

49 Jo, E. J., Lee, H. Y., Lee, Y. N., Kim, J. I., Kang, H. K., Park, D. W., Baek, S. H., Kwak, J. Y. and Bae, Y. S. (2004) Group IB secretory phospholipase $A_{2}$ stimulates CXC chemokine ligand 8 production via ERK and NF- $\kappa B$ in human neutrophils. J. Immunol. 173, 6433-6439

50 Mandal, A. K., Zhang, Z., Chou, J. Y. and Mukherjee, A. B. (2001) Pancreatic phospholipase $A_{2}$ via its receptor regulates expression of key enzymes of phospholipid and sphingolipid metabolism. FASEB J. 15, 1834-1836 